\title{
Drying and Reconstitution of Subbituminous Coal CRADA 90-004, Final Report
}

October 30, 1991

\author{
W.W. Wen \\ M.A. Nowak \\ R.P. Killmeyer
}

\author{
U.S. Department of Energy \\ Pittsburgh Energy Technology Center \\ 626 Cochrans Mills Road \\ Pittsburgh, PA 15236 \\ and \\ Amax Coal Company \\ 251 North Illinois Street \\ Indianapolis, IN 46206-6106
}

IISTRIBUTION OF THIS DOCUMENT IS UNLMITED

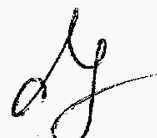




\section{Disclaimer}

This report was prepared as an account of work sponsored by an agency of the United States Government. Neither the United States Government nor any agency thereof, nor any of their employees, makes any warranty, express or implied, or assumes any legal liability or responsibility for the accuracy, completeness, or usefulness of any information, apparatus, product, or process disclosed, or represents that its use would not infringe privately owned rights. Reference herein to any specific commercial product, process, or service by trade name, trademark, manufacturer, or otherwise does not necessarily constitute or imply its endorsement, recommendation, or favoring by the United States Government or any agency thereof. The views and opinions of authors expressed herein do not necessarily state or reflect those of the United States Government or any agency thereof. 


\section{DISCLAIMER}

Portions of this document may be illegible electronic image products. Images are produced from the best available original document. 


\title{
Drying and Reconstitution of Subbituminous Coal CRADA 90-004, Final Report
}

October 30, 1991

\author{
W.W. Wen \\ M.A. Nowak \\ R.P. Killmeyer
}

U.S. Department of Energy

Pittsburgh Energy Technology Center

626 Cochrans Mills Road

Pittsburgh, PA 15236

and

Amax Coal Company

251 North Illinois Street

Indianapolis, IN 46206-6106 


\section{RECONSTITUTION OF SUBBITUMINOUS COAL}

\section{INTRODUCTION}

AMAX Coal Company (AMAX) has built a 200 tph, demonstration scale fluidized-bed drying process at their Belle Ayr Mine in Wyoming to dry the subbituminous coal of Wyodak seam from an average moisture content of $25-30 \mathrm{wt} \%$ to about $10 \mathrm{wt} \%$ [1]. Currently, the dryer generates too many fines for proper transportation and handling. Though the raw coal is about 2-inch top size, about 80 wt\% of the dryer product ends up finer than 28 mesh, and about $10 \mathrm{wt} \%$ of the dried coal is collected in the dryer bag house (minus 200 mesh). Paul Woessner, Director of Research and Development of AMAX, met with personnel from PETC Coal Preparation Division and expressed an interest in an investigation of the feasibility of applying the PETC's humic acid binder [2,3] to reconstitute the bag house fines from the dryer. This was an area in which PETC had been doing some research and had some expertise.

As a result, AMAX and the U.S. Department of Energy's Pittsburgh Energy Technology Center (PETC) signed a Cooperative Research and Development Agreement (CRADA, see appendix A) in June 1990 to produce, from fine subbituminous coal, economic low moisture reconstituted solid fuel forms that have suitable storage, handling, transportation, and combustion properties. PETC's task in this agreement was to conduct broad, baseline studies in three areas: (1) to develop a humic acid binder from AMAX subbituminous coal using the PETC-developed Humic Acid Binder Process, (2) to reconstitute AMAX's dried subbituminous coal fines from the bag house and the fluidized bed dryer product with humic acid binder, and (3) to produce low moisture, water-resistant pellets from raw subbituminous coal by the PETC-developed Lignipel Process [4,5]. AMAX, on the other hand, agreed to produce 1-2 tons of reconstituted solid fuel for handleability and combustion tests and partially funded PETC's efforts.

\section{MATERIALS, PROCESSES AND PROCEDURES}

\section{COALS}

The Wyodak seam, Belle Ayr Mine raw subbituminous coal and its bag house fines from the fluidized bed dryer of AMAX Coal Company were used for this CRADA. A chemical analysis of raw subbituminous coal is given in Table 1 . The raw coal was crushed to three different top sizes, 10,28 , and 48 mesh, for testing.

\section{HUMIC ACID BINDER PROCESS}

The humic acid binder used in this CRADA was produced from leonardite (weathered lignite) by ammonium hydroxide extraction. Tables 2 and 3 present a chemical analysis of 
leonardite and its humic acids. The advantages of humic acid binder are that it is reasonably low in production cost, the raw materials are readily available, and it produces agglomerates that are durable and weather resistant. The use of humic acid as a binder for bituminous coal pelletizing was successfully developed and patented $[2,3]$ by PETC. However, testing data on subbituminous coal were limited. Figure 1 shows the flow diagram for the humic acid preparation and pelletizing scheme [2].

\section{LABORATORY HUMIC ACIDS EXTRACTION METHODS}

\section{Method 1: Extraction, Separation and Isolation of Humic Acids From Coal}

Aqueous alkali $(100 \mathrm{ml})$ is added to 10 grams of coal and stirred at room temperature for 24 hours. The sample is placed in a bottle and centrifuged at $1000 \mathrm{rpm}$ and $10^{\circ} \mathrm{C}$ for 2 hours. The supernatant is then carefully decanted. The supernatant is heated to boiling and gravity filtered through a Whatman No. 40 filter paper or equivalent. The filtered solids were washed once with $50 \mathrm{ml}$ hot water. Concentrated HCL is added to the filtrate to bring the solution to $\mathrm{pH} 2$ and the resulting precipitate is gravity filtered through a Whatman No. 40 or equivalent filter paper and washed with $100 \mathrm{ml}$ water. If after drying, the sample on the filter paper appears to be contaminated with white crystals, the wash step is repeated. The coal residue remaining in the centrifuge bottle is subjected to this procedure as many times as deemed necessary. (If the coal used was Wyodak coal, the washed coal was mixed with alkali and the procedure repeated 3 additional times.) After subsequent extractions, boiling water $(100 \mathrm{ml})$ is added to the final coal residue in the centrifuge bottle. The mixture is stirred for 10-15 minutes then centrifuged for 2 hours. The supernatant is decanted, filtered and the filter paper washed. The filtrate and washing are combined, acidified to $\mathrm{pH} \mathrm{2,} \mathrm{and}$ the resulting precipitate filtered and washed. The coal residue in the centrifuge bottle is dried and weighed. The weight of coal fines and humic acid precipitates on the filter papers is determined.

\section{Method 2: Extraction, Dilution and Instrumental Analysis}

A sample of coal (1.00 gram) is placed in each of 5 flasks. To each flask is added 10 $\mathrm{ml}$ of 5.0 molar $\mathrm{NaOH}$ or other alkali of desired concentration. The flasks are placed in an orbital shaker. The time is recorded. After one hour, the cork is removed from the first test tube and the contents of the test tube decanted into a $500 \mathrm{ml}$ volumetric flask. The test tube is washed with additional alkali until all the material has been transferred. The contents of the volumetric flask is diluted with $5.0 \mathrm{M}$ alkali to a total of $500 \mathrm{ml}$. The flask is stoppered and the contents mixed well. The stopper is removed and $5 \mathrm{ml}$ aliquot withdrawn and transferred to a $100 \mathrm{ml}$ volumetric flask. The contents of the $100 \mathrm{ml}$ flask is diluted to mark with additional alkali. Approximately $10 \mathrm{ml}$ of the contents of the $100 \mathrm{ml}$ flask is drawn into a disposable syringe. The syringe is fitted with a disposable sub-micron $(0.2 \mu \mathrm{m})$ filter. The mixture is filtered into a cuvette so as to rinse the cuvette, the filtrate discarded and the rinse repeated. The cuvette is filled with filtrate. The wavelength on the spectrophotometer is set to $420 \mathrm{~nm}$. A second cuvette is filled with alkali. The spectrophotometer is zeroed using the 
alkali blank. The humic acid sample is inserted and the absorbance value and time are recorded. Approximately $50 \mathrm{ml}$ of the alkaline coal/water mixture is filtered into a $2 \mathrm{oz}$ amber bottle, and the bottle capped tightly.

The dilution and absorbance procedure is repeated for the second and successive test tubes at 2, 4, 8 and 24 hours respectively. All five $50 \mathrm{ml}$ samples are submitted to analytical services for total organic carbon and humic acid analyses.

\section{Analysis of Humate for Nitrogen and Ammonia Content}

Leonardite (5 grams) was slurried with $50 \mathrm{ml} 5.0 \mathrm{M} \mathrm{NH}_{4} \mathrm{OH}\left(85 \mathrm{~g} \mathrm{NH}_{3} / \mathrm{L}, 4.25 \mathrm{~g}\right.$ $\mathrm{NH}_{3}$ ) for 16 hours. The slurry was filtered, and the filtrate concentrated by distillation under vacuum (rotary evaporation). The sample was then submitted dried for 1 hour at $100^{\circ} \mathrm{C}$ or heated to $165^{\circ} \mathrm{C}$ for 24 hours. The sample was then submitted for total nitrogen titratable ammonia analyses.

\section{LIGNIPEL PROCESS}

The PETC-developed and patented Lignipel Process [4,5] is a continuous process for pelletizing and drying raw lignite to produce low moisture content pellets of sufficient strength for handling, shipping, and prolonged storage. The final pellet size ranges from 5/8 to $11 / 4$ inch in diameter, has a moisture content of about 15 percent, has a compressive strength of at least $20 \mathrm{lb}$, and is weather resistant.

The Lignipel process consists of three stages as shown in Figure 2. In the first stage, lignite is crushed and mixed with water and an asphalt emulsion for binding. The best binders for lignite were found to be a mixture of 63-percent asphalt, 1-percent emulsifier, and 36-percent water, or natural asphalt (gilsonite) at about $5 \mathrm{lb}$ per $100 \mathrm{lb}$ of lignite on dry basis. The second stage consists of pelletizing in a rotary balling pan, which operates continuously and produces 3/4-inch nominal-size pellets. In the final stage, the pellets are first dried with $270^{\circ} \mathrm{F}\left(132^{\circ} \mathrm{C}\right)$ gases, then cooled with ambient air.

\section{PELLETIZING PROCEDURE}

The general reconstitution procedure for pelletizing the fine coal was as follows. A 2000 gram fine coal sample was mixed with a prescribed amount of water in a mix muller and blended for a period of 10 minutes. Generally, about $17 \mathrm{wt} \%$ of free moisture content in the pellet feed, including the water provided from the binder, would produce the best pellet compressive strength. At this point, the binder was added to the material in the mix muller, and the mixture was stirred for another 15 minutes. Pelletizing was then performed on a 16inch laboratory disc pelletizer. The size and compressive strength of pellets from a specific feed were affected by variables such as spray water, spray position, pan speed, pan angle and feed rate. 


\section{GRADIENT DRYING PROCEDURE}

All pellets were dried in a laboratory dryer at $62^{\circ} \mathrm{C}$ for 30 minutes, and then the dryer temperature was gradually raised to the desired final higher temperature in less than one hour. By doing this, the majority of the pellet moisture was removed slowly to avoid cracking of the pellets, and therefore the dried pellets were relatively stronger than pellets dried at a higher temperature from the beginning. The drying temperatures and gradient affect the strength and weather resistance of the pellets, particularly if humic acid is the binder.

\section{RESULTS AND DISCUSSIONS}

\section{DEVELOPMENT OF HUMIC ACID BINDER FROM SUBBITUMINOUS COAL}

The objectives of this task were to characterize the raw Wyodak subbituminous coal, determine the amount of alkali extractable material from that coal, and attempt to increase the amount of alkali extractable material by oxidation of the coal.

\section{Extraction of Humic Acids from Wyodak Coal}

The humic acid derived from subbituminous coal was compared to humic acid derived from leonardite, since that is the most well-characterized system. Our initial findings, shown in Tables 4 and 5 , indicate that less than 60 weight $\%$ of leonardite is isolatable as humic acid after one single-24 hour extraction with either $\mathrm{NaOH}$ or $\mathrm{NH}_{4} \mathrm{OH}$ [6]. These findings are contrary to many reports that suggest that leonardite is nearly completely soluble in alkali. These suggestions probably arise from the very dark coloration of the extraction mixtures and the difficulty in separating the alkali soluble and insoluble fractions. Leonardite is almost as soluble in concentrated ammonium hydroxide (49\%) as it is in dilute sodium hydroxide (57\%). In comparison, raw Wyodak coal was found to be soluble in sodium hydroxide with total isolated humic acids ranging from 20 to $45 \%$ after five successive extractions. On two occasions, humic acid yields from raw Wyodak of 50 and $80 \%$ (not reported in the tables) were found to be irreproducible or unreliable due to a lack of mass balance. In order to determine if Wyodak coal could be more fully extracted, the Wyodak coal was oxidized. The data indicate that the oxidized coal is more readily extractable. These and later findings suggest that the extractability of humic acid from leonardite, raw Wyodak coal or oxidized Wyodak coal is primarily a function of the coal used and base strength, with alkali concentration of secondary importance. Raw Wyodak is more readily solubilized by sodium hydroxide, than by ammonium hydroxide, a weaker base.

When coal/alkali slurries yielded any reasonable humic acid concentration, the humic acids behaved as a glue, making any separation of humic acid and coal particles difficult and a clean separation by conventional filtration or centrifugation very difficult. Thus, attempts to extract and isolate humic acid from the extreamely fine bag house dust were futile. Neither 
eliminating fines from the coal sample prior to extraction nor the use of flocculating agents improved the rate or quality of the separations.

Because of this, an alternate procedure for determining the amount of solubilized coal was developed. The procedure used essentially the same extraction procedure, but was done on a smaller scale, and after the appropriate extraction time, the sample was diluted before being subjected to filtration through a porous membrane filter. The absorbance of the dilute solution was determined and the sample submitted to an independent laboratory to determine the amount of water soluble humic and fulvic acids. The literature [7] suggests that UV/VIS spectrophotometry can be used as a means of determining the extent of weathering in bituminous coking coals. Control experiments demonstrated that reducing the concentration of the alkali after extraction (by dilution) had no deleterious effect on humic acid yield. The yield appears to be a function of the alkali used and the higher yields obtained when dilutions were made with water as opposed to aqueous alkali suggest that too high an alkali concentration might result in a salting out effect. A salting out effect may also explain the inverse relationship between yield of humic acids obtained and sodium hydroxide concentration when raw Wyodak is extracted (Table 4). Measuring absorbance (Figure 3) can be used to determine relative trends in humic acid yields.

\section{The Rate of Extraction of Humic Acids from Oxidized Wyodak Coal}

The rate of extraction of humic acids from oxidized Wyodak coal was determined to test whether successive extractions were absolutely necessary and to determine the effect of time on extraction yield. Aliquots of the alkaline extracts withdrawn over various periods of time and the absorbance of the sample was determined to estimate of the amount of material in solution. There is a good correlation between absorbance and yield for both total organic carbon and humic acid with $r^{2}$ values of 0.98 and 0.88 , respectively. The data suggested that the rate of solubilization was asymptotic and maximum solubilization was achieved in approximately 24 hours time. Later experiments suggested that maximum solubilization of oxidized Wyodak is reached in four hours or less (Figure 4). Adjusting the volume of extraction solution for the difference (Figure 5) in concentration so that all extractions are conducted at constant moles alkali per gram coal showed no significant difference in the extraction yield. Whether sodium hydroxide solubilizes raw Wyodak by a different mechanism than weaker bases such as ammonium hydroxide may be discerned by measuring the solubilization rate as was done with the oxidized coal. A change in the shape of the asymptotic curves would lend support to the hypothesis that there are different solubilization mechanisms for raw Wyodak by sodium and ammonium hydroxides.

Humic acid extracted from leonardite was found to have an average carbon content of $56.2 \%$, approximately $90 \%$ of the carbon content of leonardite or oxidized Wyodak. Assuming humic acids derived from oxidized Wyodak coal have approximately the same carbon content, and taking into account the difference in carbon content between the starting coal and the humic acid, then the yields expressed in Table 6 as milligrams of organic carbon per liter can be expressed as percent yields soluble carbon by multiplying by a derived 
correction factor of 1.91. These results agree with the isolated yields shown in Table 5.

\section{Oxidation of Wyodak Coal}

The use of ammonium hydroxide in preparing humic acid binders has several distinct advantages. This advocated the use of oxidized Wyodak coal for the preparation of humic acid. Thus, the next effort examined efficient oxidation of Wyodak coal to maximize humic

acid extraction. Oxidation of the coal would require careful control so as not to over-oxidize the coal and produce carbon dioxide as the main product. While many methods for oxidizing coals are known, many tend to completely degrade the coal and would probably be considered too expensive or introduce elements other than oxygen into the coal. Thus, emphasis was placed on oxidizing the coal using only air or air and water. It is reported that the oxidation of bituminous coals [8] can be achieved using only air in a circulating oven, but the procedure takes six days. Research is being conducted in South Africa [9] to convert coal to humic acid as soil conditioner and fertilizer by air/water oxidation. However, the most promising result to date is a report that humic acids can be produced by oxidizing Wyodak in a fluidized bed reactor at $200^{\circ} \mathrm{C}$ in four hours [10]. Our own efforts used a standard drying oven which was fitted with a gas inlet line over which was stacked a ten-inch diameter gas distributor plate and a ten-inch 325 mesh screen to support a coal sample. Coal (50 grams, $60 \times 100$ mesh) was placed on the screen and covered with a loose fitting lid to prevent the inadvertent dispersing of the coal. Nitrogen flowed through the distributor plate until the oven was at operating temperature and then air $\left(3.67 \mathrm{SCFH}\right.$ or $1732 \mathrm{~mL} / \mathrm{min}$ at $25^{\circ} \mathrm{C}$ ) replaced the nitrogen. After the desired length of time the heat and air were turned off and nitrogen flowed through the coal sample until the coal reached room temperature. The oxidized coal was then removed and analyzed. The optimum temperature for oxidizing Wyodak coal was found to be $185^{\circ} \mathrm{C}$. The coal could be oxidized to nearly the same oxygen content as leonardite with minimal loss of coal, but temperature control was important. Too low a temperature $\left(160^{\circ} \mathrm{C}\right)$ was ineffective and too high a temperature $\left(200^{\circ} \mathrm{C}\right)$ tended to give rise to slow combustion as evidenced by the formation of ash on the surface of the coal. The results of our efforts to oxidize Wyodak coal are presented in Table 7 and Figure 6 . A twenty-four hour oxidation time gives the best compromise between recovery and oxygen content.

Wyodak-derived humic acid was not used to produce pelletized coal because the initial pelletizing results with leonardite-derived humic acids were less successful than anticipated. In addition, the pelletizing tests would have required reasonably large quantities of oxidized coal and difficulties were encountered in scaling up the simple oven oxidation of Wyodak coal. Communications with Eniricerche S.P.A. (appended) revealed that they were conducting their own research program using oxidized Wyodak coal from their fluidized bed reactor to produce humic acid binder.

\section{Ammonia Consumption}

Tests were conducted to determine how much ammonia was consumed in production 
of humic acid binder from leonardite. When five grams of starting material (nitrogen content, $1.03 \%$ ) was treated with 4.5 grams of $\mathrm{NH}_{3}$ in water. The resuting Leonardite-derived humate was found to contain $6.5 \%$ nitrogen and $3.5 \%$ titratable ammonia if dried at $100^{\circ} \mathrm{C}$. A second experiment yielded humate having nitrogen and titratable ammonia contents of 6.0 and $2.5 \%$ after heating at $165^{\circ} \mathrm{C}$ for 24 hours, an event akin to the curing step of the pelletizing process. With an average humic acid yield of approximately $50-60 \%$ this corresponds to an ammonia consumption of approximately 0.154 to $0.167 \mathrm{~g}$ (or $3.6 \%$ ) of $\mathrm{NH}_{3}$ with one third of the ammonia still in the humate present as being free, titratable ammonia.

\section{Summary}

Extraction of humic acids from raw Wyodak coal can be accomplished but requires sodium hydroxide, a stronger, non-recyclable, and thus inherently more expensive alkali than ammonium hydroxide. The Wyodak coal is readily oxidized and the oxidation can be controlled to yield a carbonaceous material with similar oxygen content and extractable humic acids as leonardite. Ammonium hydroxide extracts humic acid from oxidized Wyodak coal as readily as it does from leonardite. The yield of humic acid from the oxidized Wyodak is somewhat less than from leonardite. While in practice separation of the humate from the coal would not be done, for evaluation purposes it is necessary. The same properties that make humic acid a suitable binder for reconstituting coal make it difficult to separate from its parent coal. Because of this, alternative methods for determining the yield of humic acid from alkali extraction of coals was developed. The absorbance of humate solutions can be used quantitatively if a sufficient number of data points are collected in preparing the standardization curve.

\section{RECONSTITUTION OF BAG HOUSE FINES FROM THE FLUIDIZED BED DRYER}

The most important testing variables for pelletizing of the bag house fines are type of binder, binder dosage, pellet feed moisture, gradient drying temperature and drying time. The ranges of the testing variables were as follows.

\begin{tabular}{llr} 
Variables & \multicolumn{2}{c}{ Ranges } \\
\hline Types of Binder: & Humic Acid & $3-9 \%$ \\
& Waste Starch & $6 \%$ \\
& Asphalt Emulsion & $8 \%$ \\
& Hydrated Lime & $1-5 \%$ \\
Pelletizer Feed Moisture: & $27-41 \%$ \\
Gradient Drying Temperature: & $62-190^{\circ} \mathrm{C}$ \\
Gradient Drying Time: & $0-120 \mathrm{~min}$
\end{tabular}

There were 12 tests completed with the bag house fines. Test data are listed in 
appendix B. Test results were plotted in Figures 7-9.

\section{Effect of Humic Acid Binder Dosage and Pellet Moisture}

The effect of humic acid binder dosage on pellet compressive strength and final pellet moisture content are plotted in Figure 7. A general trend was developed in those results that the best pellet compressive strength was around a pellet moisture content of $18 \mathrm{wt} \%$. For example, the best pellet compressive strength of $23 \mathrm{lb}$ was obtained at a humic acid binder dosage of $4.5 \mathrm{wt} \%$ where the pellet moisture was around $18 \mathrm{wt} \%$. Pellet compressive strength reduced at both higher and lower pellet moisture contents. For example, at a pellet moisture content of $10 \mathrm{wt} \%$, and at humic acid binder dosage of $4.5 \mathrm{w} \%$, the pellet compressive strength reduced from $23 \mathrm{lb}$ to about $15 \mathrm{lb}$. This reduction in pellet compressive strength with the reduction of pellet moisture could be largely due to the slaking property of low rank coal.

Figure 7 also indicated that higher humic acid binder dosage was not necessary to increase the pellet strength. This is also true for using humic acid binder for the pelletizing of bituminous coal [2].

\section{Effect of Other Binders}

In order to compare the binding effect of humic acid binder with other commercially available binders, waste starch, asphalt emulsion and hydrated lime were used as binder for the pelletizing of the bag house fines. The data are plotted in Figure 8. All the binders showed similar trend between the compressive strength and the moisture content of pellets as did humic acid binder. A best pellet compressive strength of around $37 \mathrm{lb}$ was obtained at a pellet moisture content of $18.3 \mathrm{wt} \%$ with the combination of $3 \mathrm{wt} \%$ of humic acid binder and $5 \mathrm{wt} \%$ of hydrated lime. At a pellet moisture of $10 \mathrm{wt} \%$, the pellet compressive strengths were $17 \mathrm{lb}$ for the combined binder of humic acid (3\%) and lime (5\%), $13 \mathrm{lb}$ for all three binders, humic acid (4.5\%), asphalt (8\%) and starch (6\%), and $3 \mathrm{lb}$ for the hydrated lime. The hydrated lime was the least effective of all binders.

When the humic acid binder was applied to bituminous coal in previous research, durable and weather resistent bituminous coal pellets at very low pellet moisture content were obtained [2]. Heat treatment of the dried bituminous coal pellet at temperature of $100-160^{\circ} \mathrm{C}$ was necessary to develop the weather resistent pellets. The mechanism of the water resistance developed by humate coal pellets is not clearly understood yet. It could be due to decarboxylation or polymerization. However, when applying humic acid binder to a low-rank coal, the weather resistant property of the pellet could not be reached before cracking of the pellets occurred due to the slaking property of the low-rank coal. Because of this, the pellets produced from the bag house fines were not water resistant. Figure 9 shows the water resistance of pellets in terms of a water disintegration index with different binders. Pellets with both asphalt emulsion and hydrated lime binders showed water resistance with thermal drying. Pellets with waste starch binder showed some water resistance. However, pellets 
with humic acid binder did not show any water resistance as we predicted. Pellets with a combined binder of humic acid binder ( $3 \mathrm{wt} \%)$ and hydrated lime (5wt\%) showed water resistance.

\section{RAW SUBBITUMINOUS COAL DRYING AND PELLETIZING BY THE LIGNIPEL PROCESS}

The variables investigated in raw subbituminous reconstitution were particle size, types and dosage of asphalt, mixing time, and surfactant addition. Test data are plotted in Figures 10 to 16.

\section{Effect of Particle Size.}

According to the Lignipel Process, a satisfactory feed coal size appears to be minus 10 mesh, with about 50 percent within the $10 \times 50$ mesh range and 20 percent at minus 200 mesh [1]. A certain amount of fines is necessary for strong pellet production. The Wyodak seam raw subbituminous coal received from Belle Ayr Mine was crushed to three different sizes, 10 mesh by 0,28 mesh by 0 , and 48 mesh by 0 . All particle size distributions of the crushed coal are shown in Figure 10. The size distribution of 28 mesh by 0 coal met the size specification of the Lignipel Process. However, the amount of minus 200 mesh coal was not enough in the 10 mesh by 0 coal $(6 \%)$ and was too much in the 48 mesh by 0 coal (45\%).

Figure 11 shows the effect of feed particle size on pellet compressive strength of the Wyodak subbituminous raw coal with $8 \mathrm{wt} \%$ asphalt emulsion (CRS-2) binder. The best pellet strength was obtained with a coal particle size of 28 mesh by 0 . This result agreed very well with the Lignipel Process. Pellet compressive strengths of $15 \mathrm{lb}$ were obtained at a pellet moisture around 12-20 wt\%. The low pellet strength at a particle size of 10 mesh by 0 could be due to the high pellet porosity, particularly when the pellet was dry. The low pellet strength at particle size of 48 mesh by 0 could be due to the high surface area which consumed more binder and thus weakened the pellets.

\section{Effect of Asphalt Types}

Asphalt emulsions of slow setting (CSS-1h) and rapid setting (CRS-2) were tested to investigate the effect of asphalt types. The requirements and typical applications for cationic emulsified asphalt are provided by ASTM D 2397. Test results plotted in Figure 12 indicated that a pellet compressive strength of $15 \mathrm{lb}$ was obtained with the slow setting asphalt emulsion, while $10 \mathrm{lb}$ was obtained with the rapid setting emulsion. This result indicated that the slow setting asphalt emulsion is preferred over the rapid setting emulsion. From the emulsion stability point of view, the slow setting asphalt emulsion is a more stable and better dispersed emulsion than the rapid setting asphalt emulsion. Therefore, stability control of the emulsified asphalt could be a factor to improve pellet compressive strength. A better dispersed system could be achieved by increasing the mixing time, and a more stable system could be obtained by surfactant addition that also increases the zeta potential of coal particles. 


\section{Effect of Mixing Time}

Tests on the effect of mixing time were performed on Wyodak coal of 10 mesh top size with $8 \mathrm{wt} \%$ of emulsified asphalt (CRS-2). Results plotted in Figure 13 indicated that the best pellet compressive strengths of 18 and $10 \mathrm{lb}$ were obtained for 60 and 15 minutes of mixing respectively. An $8 \mathrm{lb}$ pellet compressive strength increase was reached at a pellet moisture content around $15-23 \mathrm{wt} \%$. The longer mixing time could provide a better chance for the emulsion droplets to disperse more evenly through pellet feed thus resulting in stronger pellets. In the case of using slow setting asphalt and surfactant addition, we believe that 15 minutes of mixing time should be adequate.

\section{Effect of Surfactant Addition}

The above test results indicated that a slow setting asphalt or a well-dispersed asphalt emulsion in the coal mixture is advantageous to the compressive strength of this coal pelletizing process. Because cationic asphalt emulsion was used as a binder, it is logical to use additional cationic surfactant to improve the dispersion of the asphalt emulsion within the asphalt emulsion/coal system. Dodecylammonium chloride (DAC) was therefore selected as an additive to further reduce the setting time for the emulsion.

DAC is a cationic surfactant which would adsorb on surfaces of both coal particles and asphalt droplets to make them all highly positively charged, which would lead to more repulsion of droplets and coal particles and thus improve the stability or dispersion of the system [11]. At a very high dosage of $0.5 \mathrm{lb}$ of DAC per ton of coal, and at $8 \mathrm{wt} \%$ emulsified asphalt for the 28-mesh top size Wyodak coal, the best pellet compressive strength of $16 \mathrm{lb}$ without DAC and $28 \mathrm{lb}$ with DAC, as shown in Figure 14, occurred around 15-20 wt\% pellet moisture. For the 48 mesh top sized coal, the best pellet compressive strength was doubled from $10 \mathrm{lb}$ without DAC to $20 \mathrm{lb}$ with DAC as shown in Figure 15. The addition of DAC resulted in a stronger pellet compressive strength as we anticipated.

For commercial application, a lower cost and more effective surfactant than DAC should be selected. Further, the use of an anionic asphalt emulsion as a binder could be better than the cationic asphalt emulsion in terms of efficiency and cost compatibility.

\section{Effect of Emulsified Asphalt Dosage}

The slow-setting asphalt emulsion at 4,6 , and $8 \mathrm{wt} \%$ was tested with the raw subbituminous coal of 28 mesh top size. Test results plotted in Figure 16 indicated that for pellets of $10 \mathrm{wt} \%$ moisture the best pellet compressive strengths occurred at 5,10 and $17 \mathrm{lb}$ with emulsified asphalt dosages of 4,6 , and $8 \mathrm{wt} \%$ respectively, in the presence of $0.5 \mathrm{lb}$ of DAC surfactant per ton of coal.

The best pellet compressive strength of $17 \mathrm{lb}$ occurred at $8 \mathrm{wt} \%$ asphalt emulsion (CSS-1h) with surfactant addition. This asphalt dosage seems higher than the $5 \mathrm{wt} \%$ selected 
for Lignipel Process. However, research on asphalt emulsion chemistry, such as asphalt droplet size, asphalt viscosity control and surfactant selection as discussed in previous section, should be performed to formulate a cost effective asphalt emulsion that is suitable for the low rank coal pelletizing and that would reduce the asphalt dosage to less than $5 \mathrm{wt} \%$ and improve the pellet compressive strength to higher than $20 \mathrm{lb}$.

\section{ANALYSIS OF SUBBITUMINOUS COAL PELLETS}

Based on the laboratory test results discussed in the reconstitution of the bag house fines and the raw subbituminous coal, tests No.9 and test No.26 represented the best conditions using humic acid binder and emulsified asphalt binder respectively. AMAX preferred a product moisture around $10 \mathrm{wt} \%$ or less, while the best pellet compressive strength is around $18 \mathrm{wt} \%$ moisture. Test No.9 was selected to produce the bag house fine pellets at both 10 and $18 \mathrm{wt} \%$ pellet moisture with about 13 and $22 \mathrm{lb}$ (see Figure 8 ) of pellet compressive strengths respectively. Test No. 26 was selected to produce raw subbituminous coal pellets at both 10 and $18 \mathrm{wt} \%$ pellets moisture with about 20 and $28 \mathrm{lb}$ (see Figure 14) of pellet compressive strengths respectively.

The best pellet formulation for the subbituminous bag house fines and for raw subbituminous coal were listed as follows:

1. Best Pelletizing Condition for Subbituminous Bag House Fines:

Coal particle size: $\quad 200$ mesh by 0

Pellet feed moisture: $\quad 39 \mathrm{wt} \%$

Humic acid binder, $\quad 4.5 \mathrm{wt} \%$

Mixing time: $\quad 15$ minutes

2. Pelletizing Condition for Raw Subbituminous coal:

Coal particle size: $\quad 28$ mesh by 0

Pellet feed moisture: $\quad 39 \mathrm{wt} \%$

Emulsified Asphalt: $\quad 8 \mathrm{wt} \%$ CSS-1h

Surfactant, DAC: $\quad 0.5 \mathrm{lb} / \mathrm{ton}$

Mixing Time: $\quad 60$ minutes

3. Conditions for Gradient Drying:

(1). To produce a pellet moisture of $15-18 \%$, dry pellets at $62^{\circ} \mathrm{C}$ for 30 minutes then raise to $132^{\circ} \mathrm{C}$ for 10 minutes.

(2). To produce a pellet moisture of about $8-10 \%$, dry pellets at $62^{\circ} \mathrm{C}$ for 30 minutes then raise to $132^{\circ} \mathrm{C}$ for 20 minutes. 
A larger quantity of pellets was produced according to the above test conditions for both the bag house fines and raw subbituminous coal. Each batch of coal pellets were dried following the gradient drying procedure to produce pellets at both the best compressive strength and at $10 \mathrm{wt} \%$ moisture content. The four products were sent to AMAX's R \& D Center in Golden, Colorado for friability testing and pellet property measurements such as moisture content, compressive strength, bulk density, and apparent density.

Table 8 lists the pelletizing conditions, pellet properties measured by AMAX and by PETC, and the friability test results. The results indicated that the spherical pellets prepared at PETC using asphalt and humic acid binders exhibited generally lower strength and greater friability than binderless briquettes prepared from similar coals during tests performed by AMAX Coal Company.

Longer pellet curing time, which resulted in lower product moisture contents, led to reduced strength and greater friability. The results of the opacity tests, which were performed on the friability test products, indicated a high level of dust due to the production of significant amounts of $<100$ mesh material during the friability tests.

A correlation between the pellet friability and compressive strength seems possible assuming that at 0 compressive strength the friability is $100 \%$. Figure 17 shows this correlation for the bag house fines and for the raw subbituminous coal. Because of the limited data this linear correlation remains questionable. More handlability tests are needed to define an adequate pellet compressive strength that would provide the minimum friability for coal handling, transportation, and storage.

\section{SUMMARY}

\section{DEVELOPMENT OF HUMIC ACID BINDER FROM SUBBITUMINOUS COAL}

- Extraction of humic acids from raw Wyodak coal can be accomplished but requires sodium hydroxide, a stronger, non-recyclable, and thus inherently more expensive alkali than ammonium hydroxide.

o The Wyodak coal is readily oxidized and the oxidation can be controlled to yield a carbonaceous material with similar oxygen content and extractable humic acids as leonardite.

o Ammonium hydroxide extracts humic acid from oxidized Wyodak coal as readily as it does from leonardite. The yield of humic acid from the oxidized Wyodak is somewhat less than that from leonardite. 
- For bag house fines, the best pellet compressive strength of $23 \mathrm{lb}$ was developed with $4.5 \mathrm{wt} \%$ of humic acid binder, $39 \mathrm{wt} \%$ of total feed moisture and an $18 \mathrm{wt} \%$ final pellet moisture. If a pellet moisture of $10 \%$ is desirable the pellet compressive strength will drop to $15 \mathrm{lb}$.

- The best pellet compressive strength developed with different binders is in the range of $35,22,21,20$ and $16 \mathrm{lb}$ for combined humic acid (3\%) and hydrated lime (5\%), humic acid (4.5\%), emulsified asphalt (8\%), starch $(6 \%)$, and hydrated lime $(5 \%)$ respectively.

o For a weather resistant property of the pellets, the best binders are, in decreasing order, emulsified asphalt, hydrated lime, starch and humic acids.

\section{RAW SUBBITUMINOUS COAL DRYING \& PELLETIZING BY THE LIGNIPEL PROCESS}

- The best particle size distribution for pelletizing is minus 28 mesh with about 50 percent within the $10 \times 50$ mesh range and 20 percent minus 200 mesh.

The DAC surfactant addition of $0.5 \mathrm{lb}$ per ton seems to improve the stability or the dispersion of the system to increase the pellet compressive strength from 16 to $28 \mathrm{lb}$ at $15 \mathrm{wt} \%$ of pellet moisture.

A slow-setting emulsified asphalt is better than a rapid-setting emulsified asphalt in terms of pellet compressive strength. A well-dispersed or a more stable coal-binder system, whether due to thorough mixing or surfactant addition, is beneficial to pellet compressive strength development.

- A correlation between pellet friability and pellet compressive strength seems possible assuming that at 0 compressive strength the friability is 100 .

\section{FUTURE WORK}

- Study the combination of humic acids, emulsified asphalt and fiber as binders for pelletizing of both bag house fines and raw subbituminous coal.

o Perform handlability tests in truck loads to establish the correlation among the pellet compressive strength, pellet friability, wind erosion and dust pollution.

- Develop an oxidation process to produce from 1 to 5 pounds of oxidazed subbituminous coal for humic acid binder tests. 


\section{REFERENCES}

1. Anonymous, "AMAX Building Large Coal Drying Plant at its Belle Ayr Mine," Technology News, Mining Engineering, November 1988.

2. Wen, W.W., P.D. Bergman, and A.W. Deurbrouck,"A Humic Acid Binder for Pelletizing of Fine Coal," Proceedings for the 10th International Coal Preparation Congress, Edmonton, Canada, September 1-5, 1986.

3. Wen, W.W., "Fuel Agglomerates and Method of Agglomeration," U.S. Patent No. $4,615,712$ Oct. $7,1986$.

4. Baker, A.F., R.E. McKeever and A.W. Deurbrouck, "Development and Demonstration of a Lignite Pelletizing Process," U.S. DOE Report of Investigations, DOE/RI/PMTC. 12-82, March 1982.

5. Baker, A.F., E.W. Blaustein, A.W. Deurbrouck, J.P. Garvin, and R.E. McKeever, "Lignite Pellets and Methods of Agglomerating or Pelletizing," U.S. Patent No. 4,302,209 Nov. 24, 1981.

6. Schwartz, D., Personal Communication, 1990.

(Initial extraction procedure based on personal communication with Professor Donald Schwartz, University of Colorado. Prof. Schwartz suggests that these coals are completely soluble in alkali if a sufficient number of successive extraction are made. By declining to name a specific number or even a range of numbers of repeated extractions he was suggesting to me that complete solubilization of leonardite and similar coals is impractical.)

7. Lowenhaupt, D.E., and R. Gray, International Journal of Coal Geology, $1,63,1980$.

8. Friedman, L.D., and C.R. Kinney, Industrial and Engineering Chemistry, 42(12), 2525, 1950.

9. Dekker, J., I.J. Cronje, H.B. Louwrens and H. Swart, Proceedings of the Seventh International Pittsburgh Coal Conference, p 703, 1990.

10. Valemma, V. and R. Rausa, Eur. Pat. Appl. EP 272,737, 1988.

11. Wen, W.W., "Electrokinetic Behavior and Flotation of Oxidized Coal," Ph.D Thesis, The Pennsylvania State University, University Park, PA., 1977. 
Table 1. Chemical Analysis of AMAX Raw Subbituminous Coal, Wyodak Seam, Belle Ayr Mine.

\begin{tabular}{lccc} 
PROXIMATE ANALYSIS & \multicolumn{1}{c}{ A/R } & & Dry \\
Moisture \% & 30.00 & - \\
Ash \% & 4.62 & 6.60 \\
Volatile \% & 35.54 & 50.77 \\
Fixed Carbon \% & 29.84 & 42.63 \\
HHV - BTU/b & \multicolumn{2}{c}{12990}
\end{tabular}

\section{ULTIMATE ANALYSIS}

$\begin{array}{lcc}\text { Moisture \% } & 30.00 & - \\ \text { Carbon } & 49.01 & 70.01 \\ \text { Hydrogen } & 3.35 & 4.79 \\ \text { Nitrogen } & 0.71 & 1.02 \\ \text { Chlorine } & <0.01 & <0.01 \\ \text { Sulfur } & 0.34 & 0.49 \\ \text { Oxygen (Diff.) } & 11.96 & 17.08\end{array}$

\section{SULFUR FORMS}

Pyritic Sulfur

Organic Sulfur

Sulfate

FUSION TEMP. ${ }^{\circ} \mathrm{C}$

Initial Deform.

Soften. $(\mathrm{H}=\mathrm{W})$

Soften. $(\mathrm{H}=1 / 2 \mathrm{~W})$

Fluid

\section{MISCELLANEOUS}

Hardgrove Grind.

Equil. Moisture. \%

Free Swell. Index

Sol. Alk. \% Na2O, DCB

Sol. Akl. \% K2O, DCB

Sol.Akl. Metal \%

Alk. as Na2O \%, DCB

Silica Value

$\begin{array}{rr}0.06 & 0.09 \\ 0.27 & 0.39 \\ <0.01 & <0.01\end{array}$

\section{$\underline{\text { Reducing } \text { Oxidizing }}$}

2127

2156

2165

2183

2194

2225

2249

2290
65

26.97

0

0.084

0.007

102.11

0.09

43 
Table 2. Chemical Analysis of Leonardite*

\begin{tabular}{|c|c|c|c|}
\hline ANALYSIS & & RESULT & \\
\hline PROXIMATE ANALYSIS & [AS RECE.] & [MOIST. FREE] & [M\&A FREE] \\
\hline Moisture & 9.47 & N/A & N/A \\
\hline Volatile Matter [MOD] & 41.12 & 45.43 & 55.20 \\
\hline Fixed Carbon & 33.38 & 36.86 & 44.80 \\
\hline Ash & 16.03 & 17.71 & N/A \\
\hline ULTIMATE ANALYSIS & & & \\
\hline Hydrogen & 3.91 & 3.16 & 3.84 \\
\hline Carbon & 48.11 & 53.15 & 64.58 \\
\hline Nitrogen & 0.96 & 1.06 & 1.29 \\
\hline Sulfur & 1.07 & 1.18 & 1.43 \\
\hline Oxygen [IND] & 29.92 & 23.75 & 28.86 \\
\hline Ash & 16.03 & 17.71 & N/A \\
\hline $\begin{array}{l}\text { HEATING VALUE } \\
\text { [BTU/LB] }\end{array}$ & 7424 & 8201 & 9965 \\
\hline FREE SWELLING INDEX & 0.0 & & \\
\hline FUSIBILITY OF ASH & & & \\
\hline Initial Deformation & $2080^{\circ} \mathrm{F}$ & & \\
\hline Softening Temp & $2105^{\circ} \mathrm{F}$ & & \\
\hline Hemi Temp & $2110^{\circ} \mathrm{F}$ & & \\
\hline Fluid Temp & $2115^{\circ} \mathrm{F}$ & & \\
\hline
\end{tabular}

* Sample obtained from American Colloid Company in March 1987. 
Table 3. Chemical Analysis of Humic Acid Binder ANALYSIS RESULT PROXIMATE ANALYSIS [AS RECE.] [MOIST. FREE] [M\&A FREE]

Moisture
Volatile Matter [MOD]
Fixed Carbon
Ash
ULTIMATE ANALYSIS

$\begin{array}{lc}\text { Hydrogen } & 3.80 \\ \text { Carbon } & 49.64 \\ \text { Nitrogen } & 3.94 \\ \text { Sulfur } & 1.05 \\ \text { Oxygen [IND] } & 23.48 \\ \text { Ash } & 18.08 \\ & \\ \text { HEATING VALUE } & 7684 \\ \quad \text { [BTU/LB] } & \\ \text { FREE SWELLING INDEX } & 0.0 \\ & \\ \text { FUSIBILITY OF ASH } & \\ & \\ \text { Initial Deformation } & 2026^{\circ} \mathrm{F} \\ \text { Softening Temp } & 2133^{\circ} \mathrm{F} \\ \text { Hemi Temp } & 2143{ }^{\circ} \mathrm{F} \\ \text { Fluid Temp } & 2152^{\circ} \mathrm{F}\end{array}$


Table 4. Extraction of Humic Acid from Leonardite and Wyodak Coals with Alkali

\begin{tabular}{cccc} 
Coal Sample & Alkali & Yield Humic Acid, \% & Mass Balance, \\
\hline Leonardite & $0.5 \mathrm{M} \mathrm{NaOH}$ & 57 & 86 \\
Leonardite & $5.0 \mathrm{M} \mathrm{NH}_{4} \mathrm{OH}$ & 49 & 100 \\
Raw Wyodak & $0.1 \mathrm{M} \mathrm{NaOH}$ & 22 & 80 \\
Raw Wyodak & $1.0 \mathrm{M} \mathrm{NaOH}$ & 40 & 97 \\
Raw Wyodak & $5.0 \mathrm{M} \mathrm{NaOH}$ & 26 & 97 \\
Raw Wyodak & $0.5 \mathrm{M} \mathrm{NH}_{4} \mathrm{OH}$ & 8 & 78 \\
Raw Wyodak & $5.0 \mathrm{M} \mathrm{NH}_{4} \mathrm{OH}$ & 2 & 92 \\
Amax Drier & & & 92 \\
Product & $5.0 \mathrm{M} \mathrm{NH}_{4} \mathrm{OH}$ & 6 & 92 \\
Oxidized Wyodak & $0.5 \mathrm{M} \mathrm{NH}_{4} \mathrm{OH}$ & 2 & 100 \\
Oxidized Wyodak & $5.0 \mathrm{M} \mathrm{NH}_{4} \mathrm{OH}$ & 56 & \\
\hline
\end{tabular}


Table 5. Yield of Isolated Humic Acids for Successive Extractions

Yield for Each Successive Extraction

\begin{tabular}{llrrrrrr} 
Coal & Alkali & 1st & 2nd & 3rd & 4th & 5th & Cumulative \\
\hline Leonardite & $0.5 \mathrm{M} \mathrm{NaOH}$ & 57 & & & & & 57 \\
Leonardite & $5.0 \mathrm{M}$ & 49 & & & & & 49 \\
& $\mathrm{NH}_{4} \mathrm{OH}$ & & & & & & \\
Raw Wyodak & $0.5 \mathrm{M} \mathrm{NaOH}$ & 19 & 16 & 10 & & & 45 \\
Raw Wyodak & $1.0 \mathrm{M} \mathrm{NaOH}$ & 10 & 8 & 4 & 10 & 1 & 33 \\
Raw Wyodak & $5.0 \mathrm{M} \mathrm{NaOH}$ & 8 & 2 & 2 & 3 & 5 & 20 \\
Oxidized & $0.5 \mathrm{M}$ & 2 & & & & & 2 \\
Wyodak & $\mathrm{NH}_{4} \mathrm{OH}$ & & & & & & \\
Oxidized & $5.0 \mathrm{M}$ & 56 & & & & & 56 \\
Wyodak & $\mathrm{NH}_{4} \mathrm{OH}$ & & & & & & \\
\hline
\end{tabular}


Table 6. Absorption vs Yield of Humic Acids (HA) and Fulvic Acids (FA)

Time, hrs

\begin{tabular}{crrr} 
Time, hrs & $\begin{array}{c}\text { Absorbance } \\
\text { mg C/L }\end{array}$ & $\begin{array}{c}\text { Yield, FA } \\
\mathrm{mg} \mathrm{C} / \mathrm{L}\end{array}$ \\
\hline 1 & $5.0 \mathrm{M} \mathrm{NaOH}$ & 11 & 15 \\
2 & 0.720 & 21 & 14 \\
4 & 0.860 & 19 & 15 \\
8 & 0.880 & 21 & 11 \\
24 & 0.800 & 25 & 11 \\
& 0.780 & & \\
1 & $0.5 \mathrm{M} \mathrm{NaOH}^{2}$ & 2 & 2 \\
2 & 0.060 & 3 & 2 \\
4 & 0.060 & 4 & 1 \\
8 & 0.055 & 4 & 1 \\
24 & 0.060 & 2 & 1 \\
& 0.063 & & 6 \\
1 & $5.0 \mathrm{M} \mathrm{NH}_{4} \mathrm{OH}$ & 13 & 7 \\
2 & 0.445 & 21 & 6 \\
4 & 0.560 & 20 & 6 \\
8 & 0.595 & 23 & 5 \\
24 & 0.600 & 24 & 6
\end{tabular}
mg C/L $\mathrm{mg} \mathrm{C} / \mathrm{L}$

Absorbance

Yield, HA

Yield, FA 
Table 7. Oxidation of Wyodak Coal

\begin{tabular}{ccccccc}
$\begin{array}{l}\text { Time, } \\
\text { hours }\end{array}$ & $\begin{array}{l}\text { Recovered } \\
\text { Weight, } \\
\%\end{array}$ & $\begin{array}{l}\text { Dry } \\
\text { Recovery, } \\
\%^{1}\end{array}$ & $\begin{array}{l}\text { Oxygen } \\
\text { Content, \% }\end{array}$ & $\begin{array}{l}\text { Ash } \\
\text { Content, } \%\end{array}$ & $\begin{array}{l}\text { Carbon } \\
\text { Content, \% }\end{array}$ & $\begin{array}{c}\text { Carbon } \\
\text { Recov'd, \% }\end{array}$ \\
\hline 0 & 100 & 100 & 13.97 & 8.38 & 71.67 & 100 \\
3 & --- & -- & 22.83 & 8.23 & 65.15 & ---- \\
6 & --- & --- & 24.32 & 8.20 & 63.91 & ---- \\
24 & 70 & 90 & 27.81 & 7.95 & 61.57 & 76 \\
24 & 82 & 105 & 30.80 & 6.95 & 62.46 & 92 \\
48 & 75 & 96 & 28.93 & 7.86 & 61.03 & 82 \\
72 & 70 & 88 & 31.75 & 7.56 & 60.08 & 74 \\
96 & 67 & 87 & 31.38 & 7.50 & 58.88 & 71 \\
\hline
\end{tabular}

1. Oxidation was conducted at $185^{\circ} \mathrm{C}$ using compressed air. Recovery and analytical results are reported on a moisture free basis. The moisture content of the starting coal and product coal were nominally $27 \%$ and $3 \%$, respectively. 
Table 8. Analysis of Subbituminous Coal Pellets

\begin{tabular}{ll} 
Raw Subbituminous Coal & \multicolumn{2}{l}{ Dried Baghouse Dust } \\
Sample 1 & Sample 3
\end{tabular}

Pellet Preparation

Feed Moisture, \%

Binder Type

Binder Conc., \%

Green Pellet Moisture, \%

Pellet Drying Conditions

Time at $62^{\circ} \mathrm{C}$, Minutes

Time at $132^{\circ} \mathrm{C}$, Minutes

\section{Pellet Properties}

Moisture, \%

PETC

AMAX

Proximate Analysis, \% (Dry)

Ash

Volatile Matter

Fixed Carbon

Compression Strength, ib

PETC

AMAX

Bulk Density, $\mathrm{lb} / \mathrm{ft}^{3}$

Apparent Density, $\mathrm{lb} / \mathrm{ft}^{3}$
40.4

Asphalt

8

41.3

30

10

17.8

16.1

7.08

46.53

46.39

27.4

28.5

35.2

64.8
40.4

Asphalt

8

40.3

30

20

8.6

8.9

18.0

16.9

8.4

18.1

12.48

38.12

49.40

46.65

46.59

26.2

7.5

37.0

60.6
12.27

38.93

48.80

13.7

14.9

37.7

35.8

82.8
39.1

4.5

39.6

30

20

Notes: Pellet preparation conditions were supplied by PETC.

Pellet properties were determined by AMAX R\&D except as noted.

Sample 2 arrived with a tag indicating that raw coal was used; data inside the bag indicated that baghouse dust was used. 
Table 8. Analysis of Subbituminous Coal Pellets (Continued)

Raw Subbituminous Coal Sample 1 Sample 3
Dried Baghouse Dust Sample 4 Sample 2

Friability Test Results

Tumbler Feed Particle Size Analysis, \%

$>1$ inch

$1 \times 3 / 4$ Inch

0.4

38.0

9.4

29.2

$3 / 4 \times 1 / 2$ inch

47.0

31.2

$1 / 2 \times 3 / 8$ inch

9.9

9.0

1.6

12.0

$1 / 4$ Inch $\times 6$ Mesh

0.9

$6 \times 16$ Mesh

0.7

$16 \times 48$ Mesh

0.7

3.8

0.6

$48 \times 100$ Mesh

0.3

$<100$ Mesh

Average Feed Size, Inch

0.5

0.5

30.2

22.9

28.9

36.6

13.4

19.3

5.8

4.3

6.6

5.3

9.6

6.1

3.2

3.4

1.2

0.3

2.1

0.6

0.4

0.682

2.2

0.5

1.4

0.653

0.782

0.777

Tumbled Product Particle

Size Analysis, \%

$>1$ inch

$1 \times 3 / 4$ inch

$3 / 4 \times 1 / 2$ inch

$1 / 2 \times 3 / 8$ Inch

$3 / 8 \times 1 / 4$ Inch

$1 / 4$ Inch $\times 6$ Mesh

$6 \times 16$ Mesh

$16 \times 48$ Mesh

$48 \times 100$ Mesh

$<100$ Mesh

Average Product Size, Inch

Friability, \%

Opacity Test Results

\% Light Transmission at

Indicated Elapsed Time

15 Seconds

60 Seconds
1.9

21.0

23.8

7.8

1.0

0.1

0.2

20.9

11.6

11.7

0.400

41.5
0.9

5.1

1.9

1.5

0.9

1.2

11.0

39.1

25.3

13.1

0.101

84.5
10.2

27.1

14.1

4.2

0.3

0.2

0.2

14.7

16.0

13.0

0.478

39.0
3.3

14.4

11.8

5.4

2.4

1.3

2.3

14.5

21.0

23.6

0.283

63.5

Notes: Friability tests were based on ASTM D441, "Tumbler Test for Coal". Results represent the percent reduction of average particle size.

Opacity measurements represent light transmission through the dust cloud at the indicated elapsed times after dropping sample into the test apparatus. 


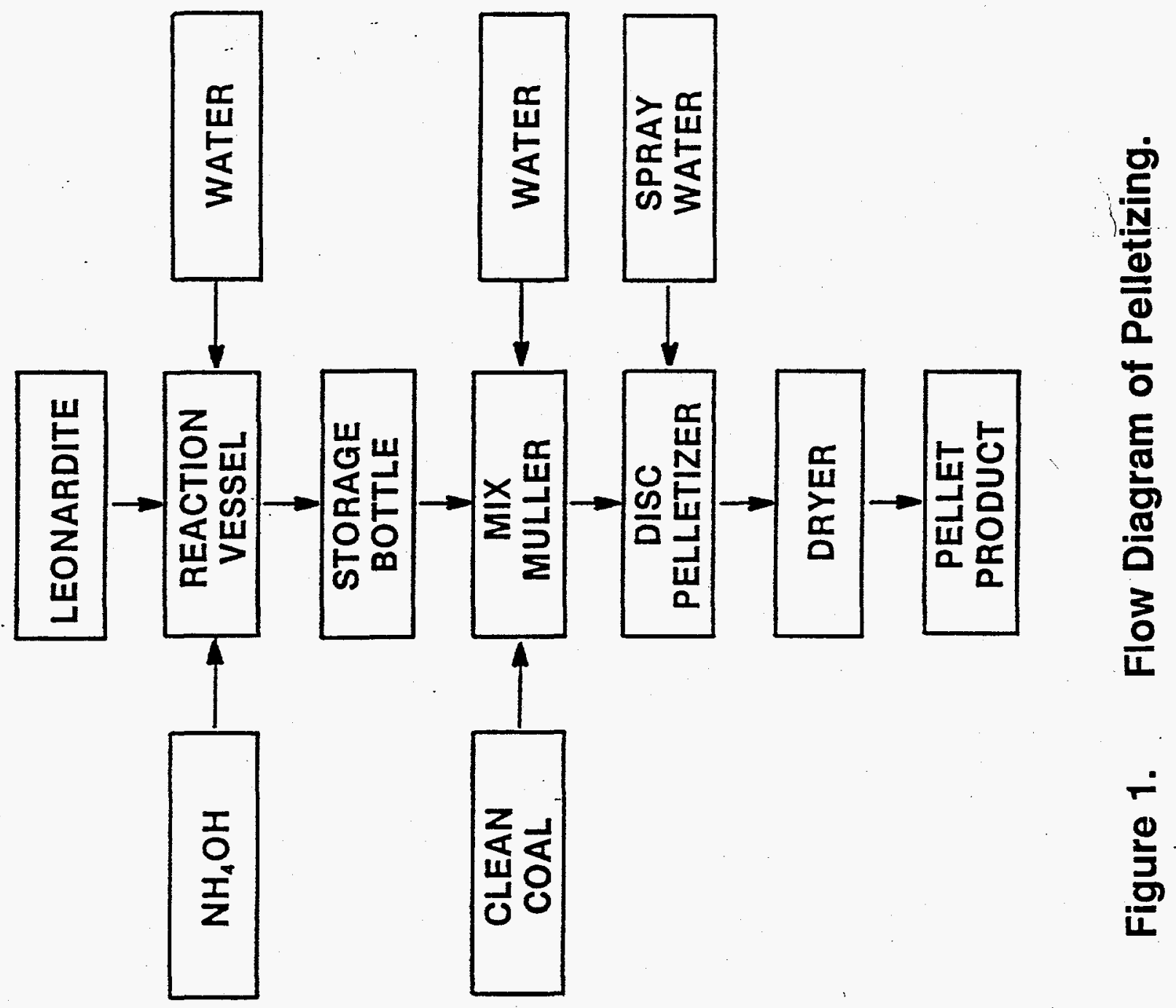



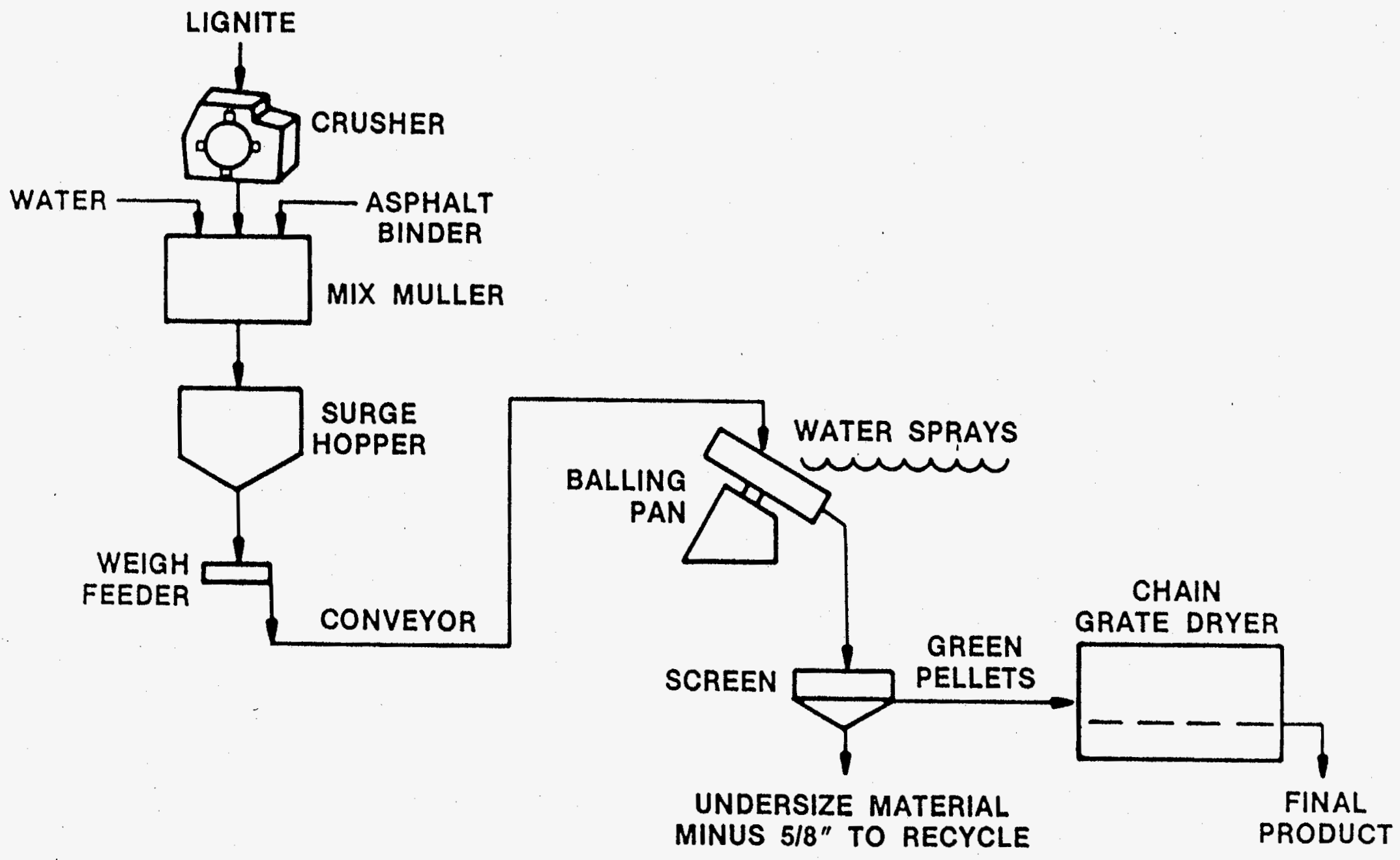

Figure 2. Lignipel Process Flow Sheet. 


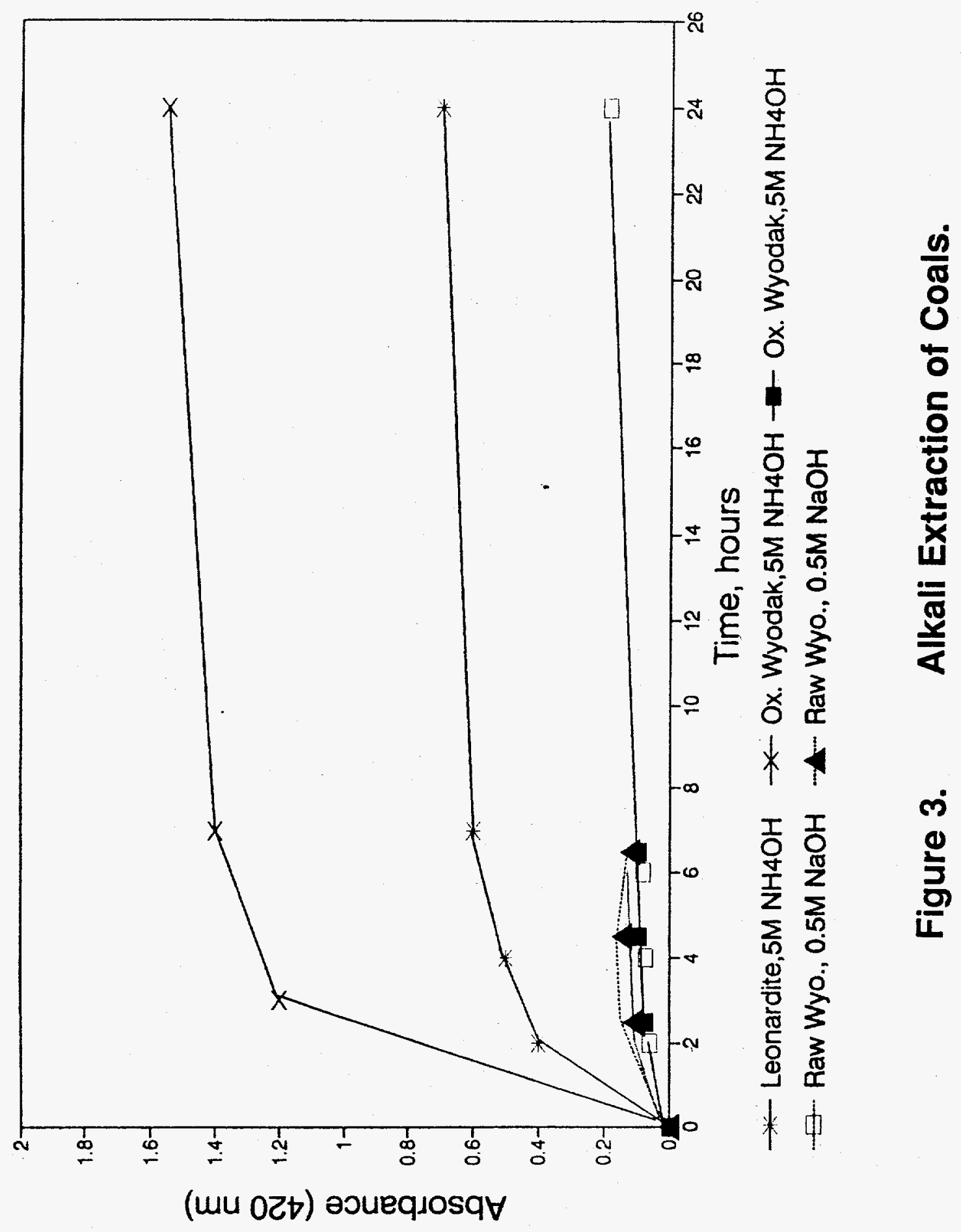




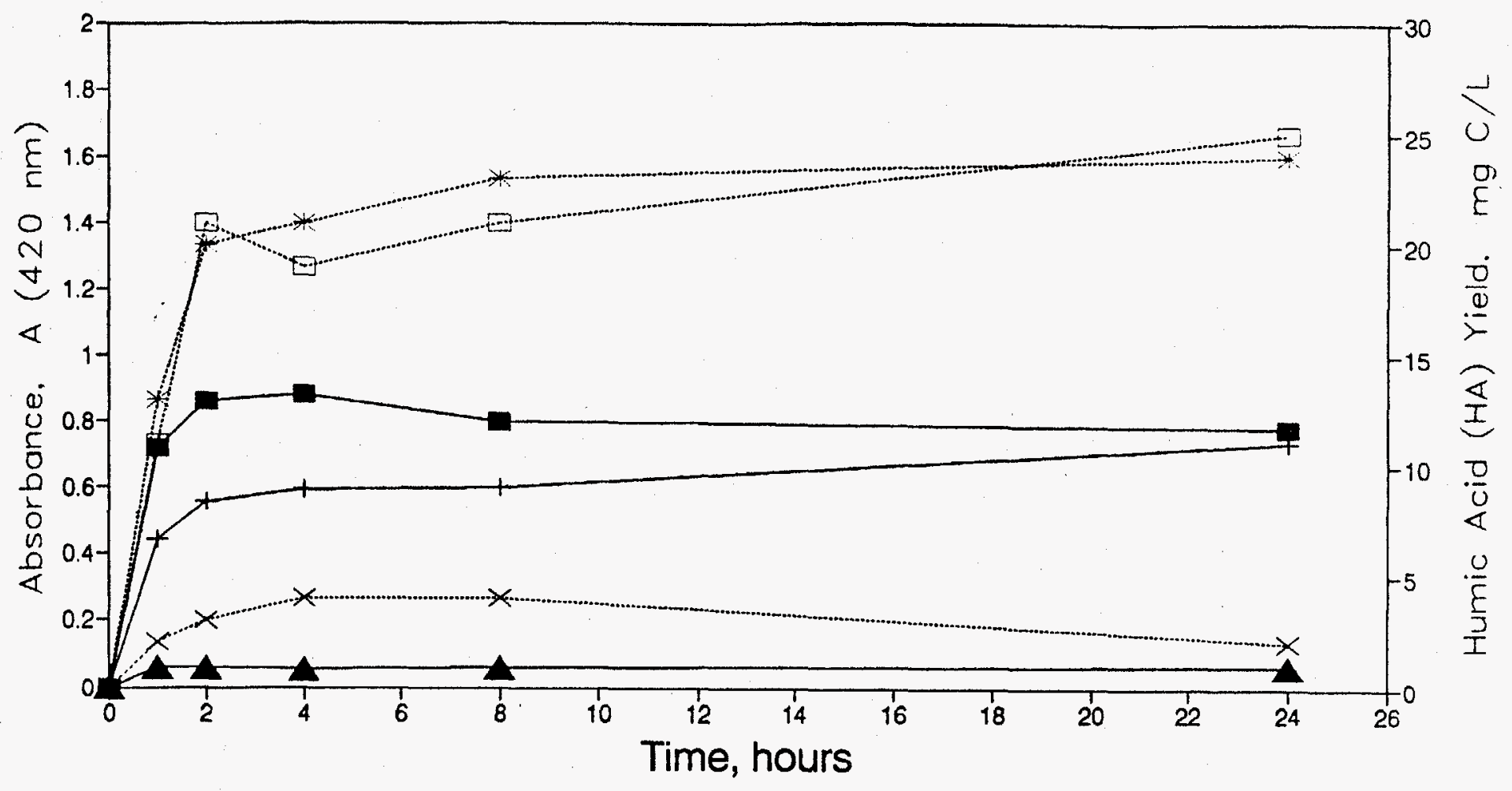

$\rightarrow$ A, $5.0 \mathrm{M} \mathrm{NaOH} \rightarrow \mathrm{A}, 0.5 \mathrm{M} \mathrm{NaOH} \rightarrow \mathrm{A}, 5.0 \mathrm{M} \mathrm{NH} 4 \mathrm{OH}$
$-\cdots \mathrm{HA}$ Yield, $5 \mathrm{M} \mathrm{NaOH}$ - $\rightarrow$ Yield, $0.5 \mathrm{M} \mathrm{NaOH} \cdots \mathrm{HA}$ Yield, $5 \mathrm{M} \mathrm{NH} 4 \mathrm{OH}$

Figure 4. Alkali Extraction of Oxidized Wyodak. 


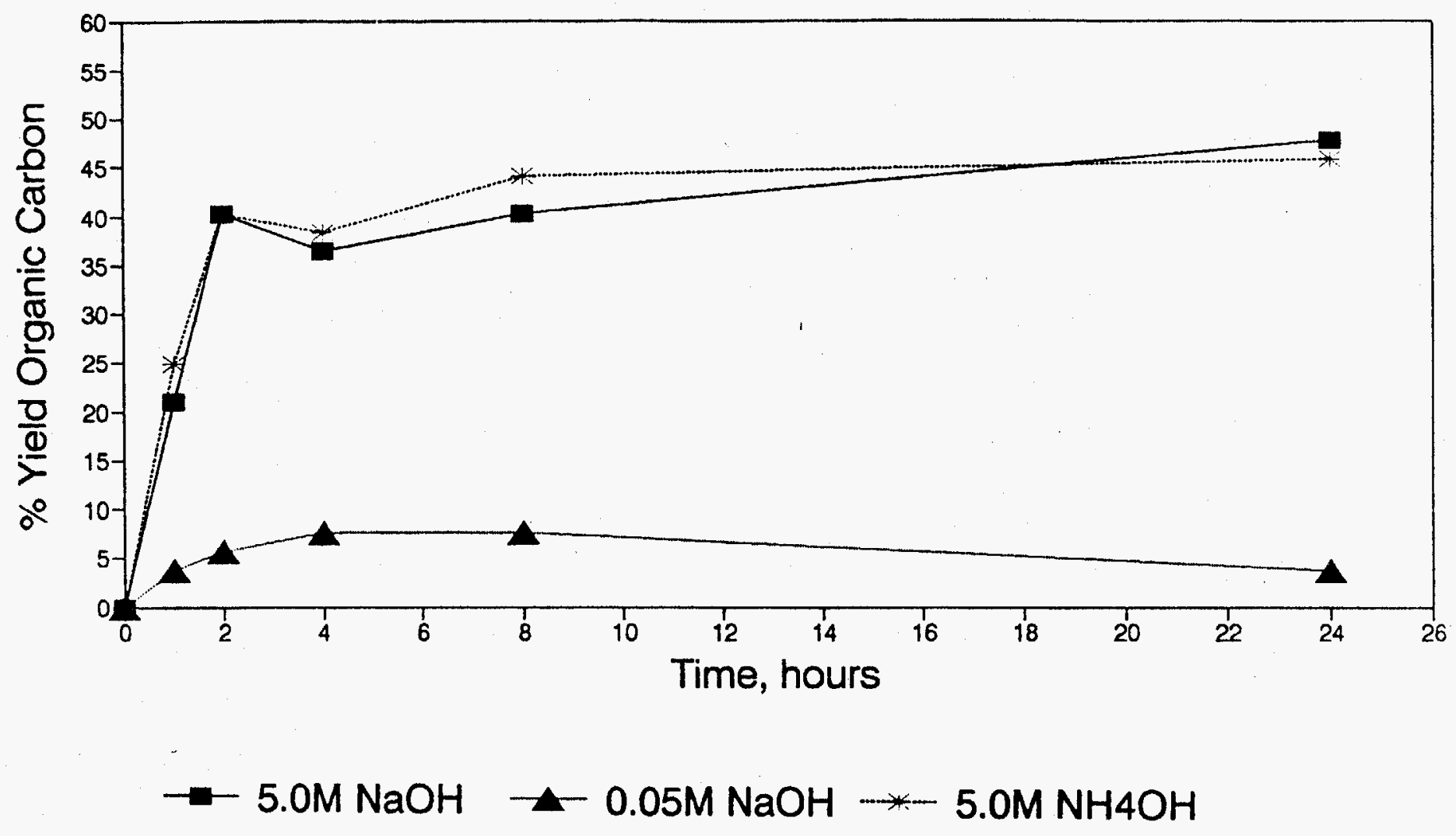

Figure 5. Yield Organic Carbon vs Extraction Time for Fixed Moles Alkali Oxidized Coal. 


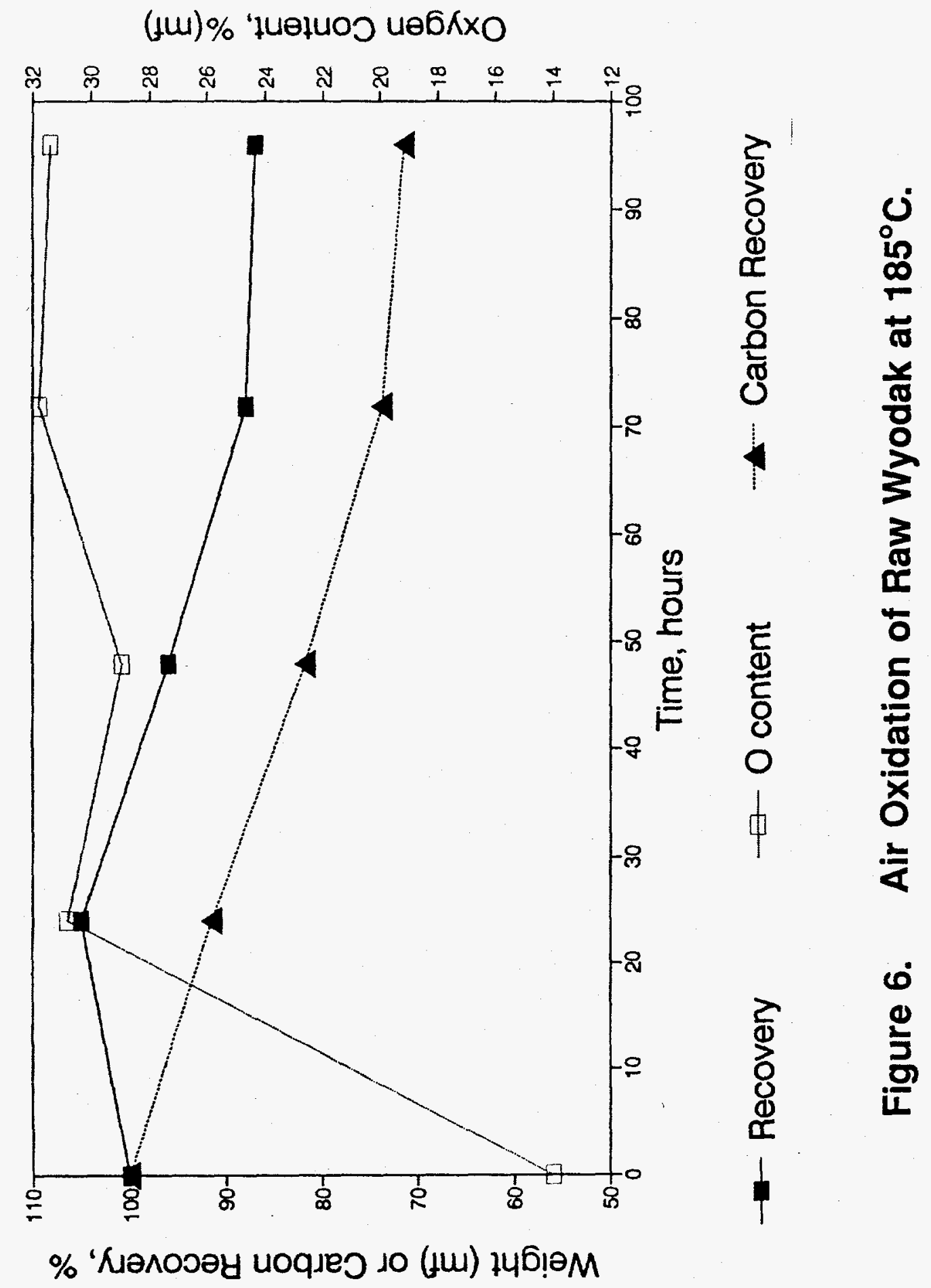




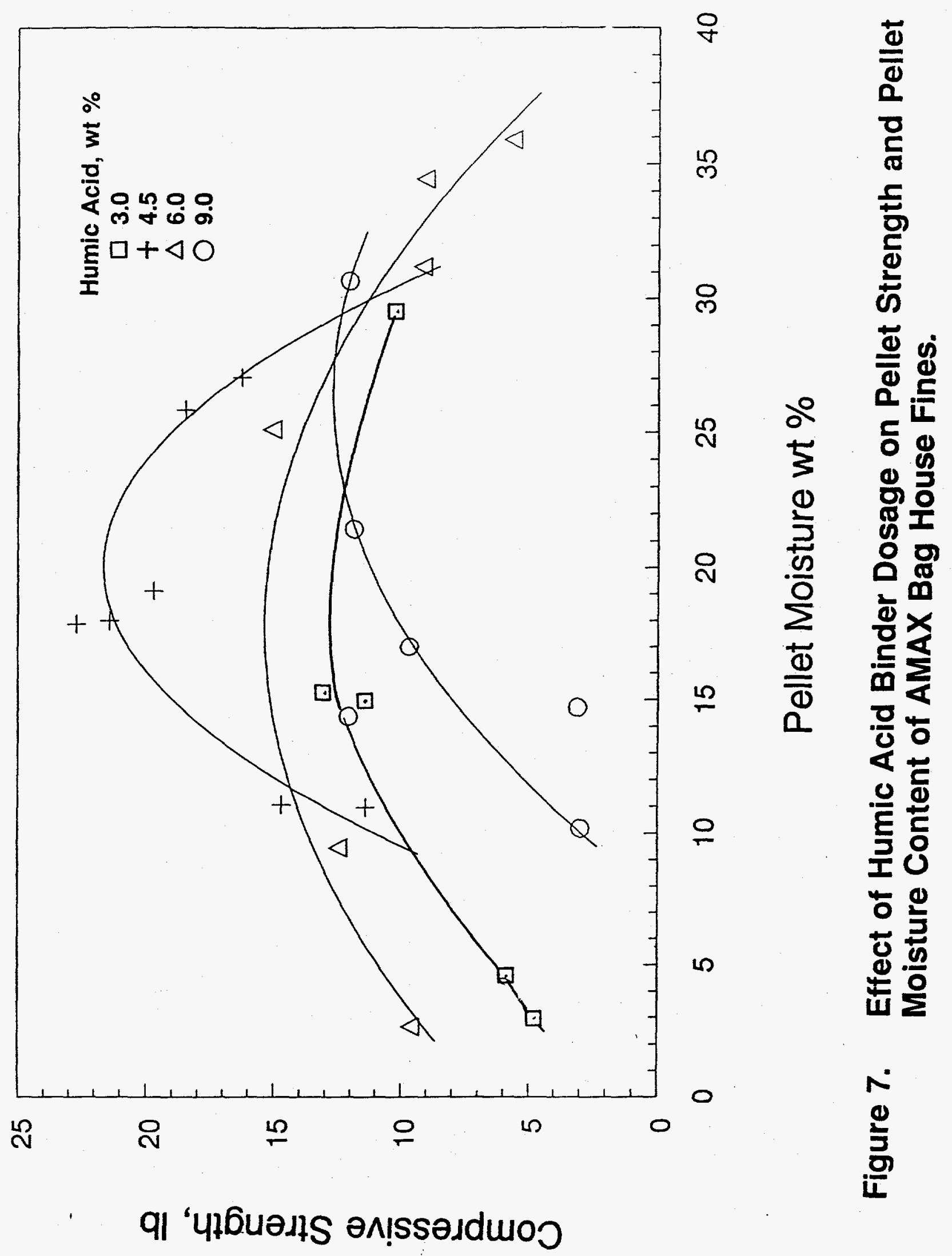




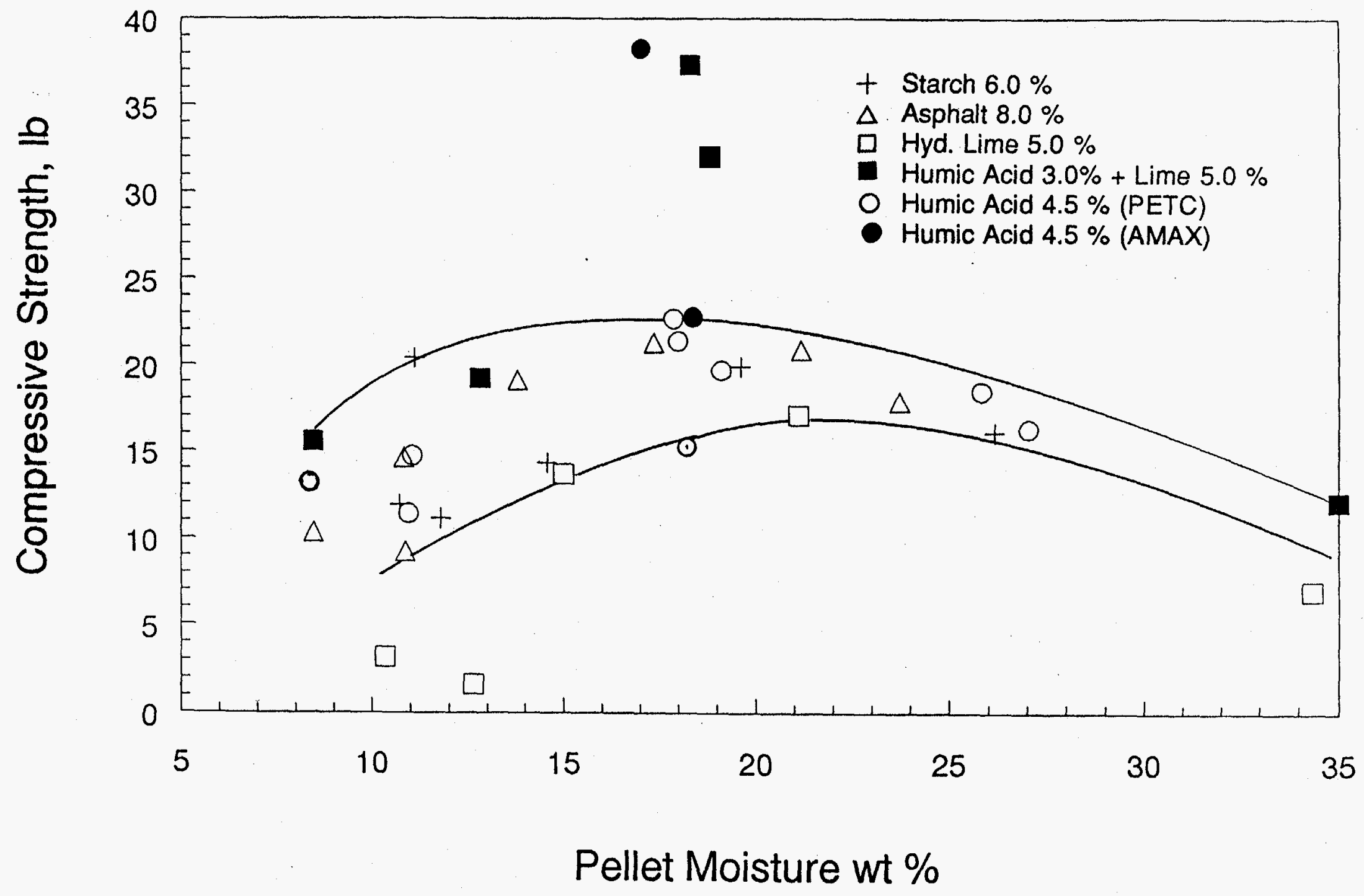

Figure 8. Effect of Binder Types on Pellet Strength and Pellet Moisture Content of AMAX Bag House Fines. 


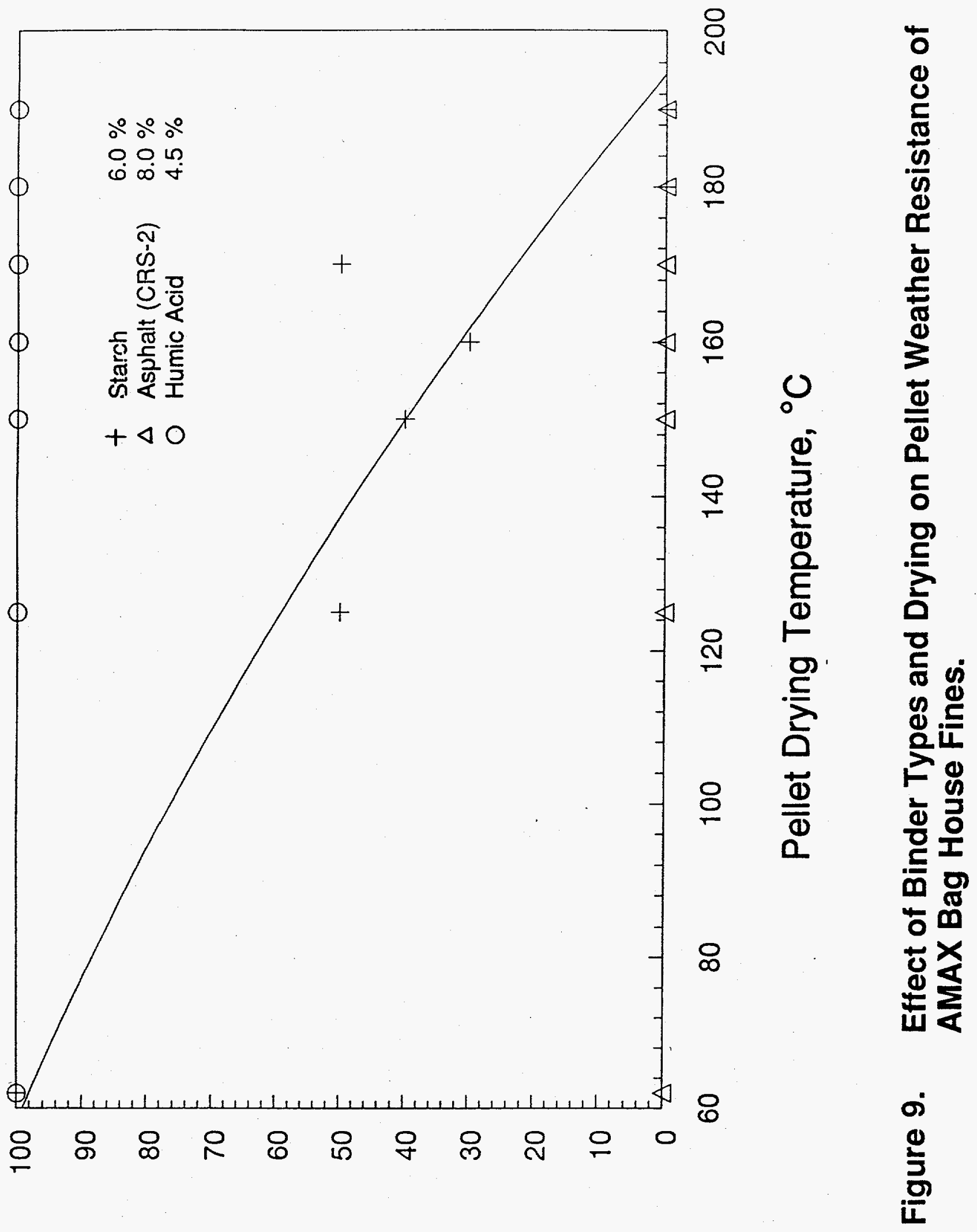

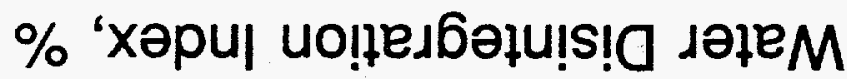




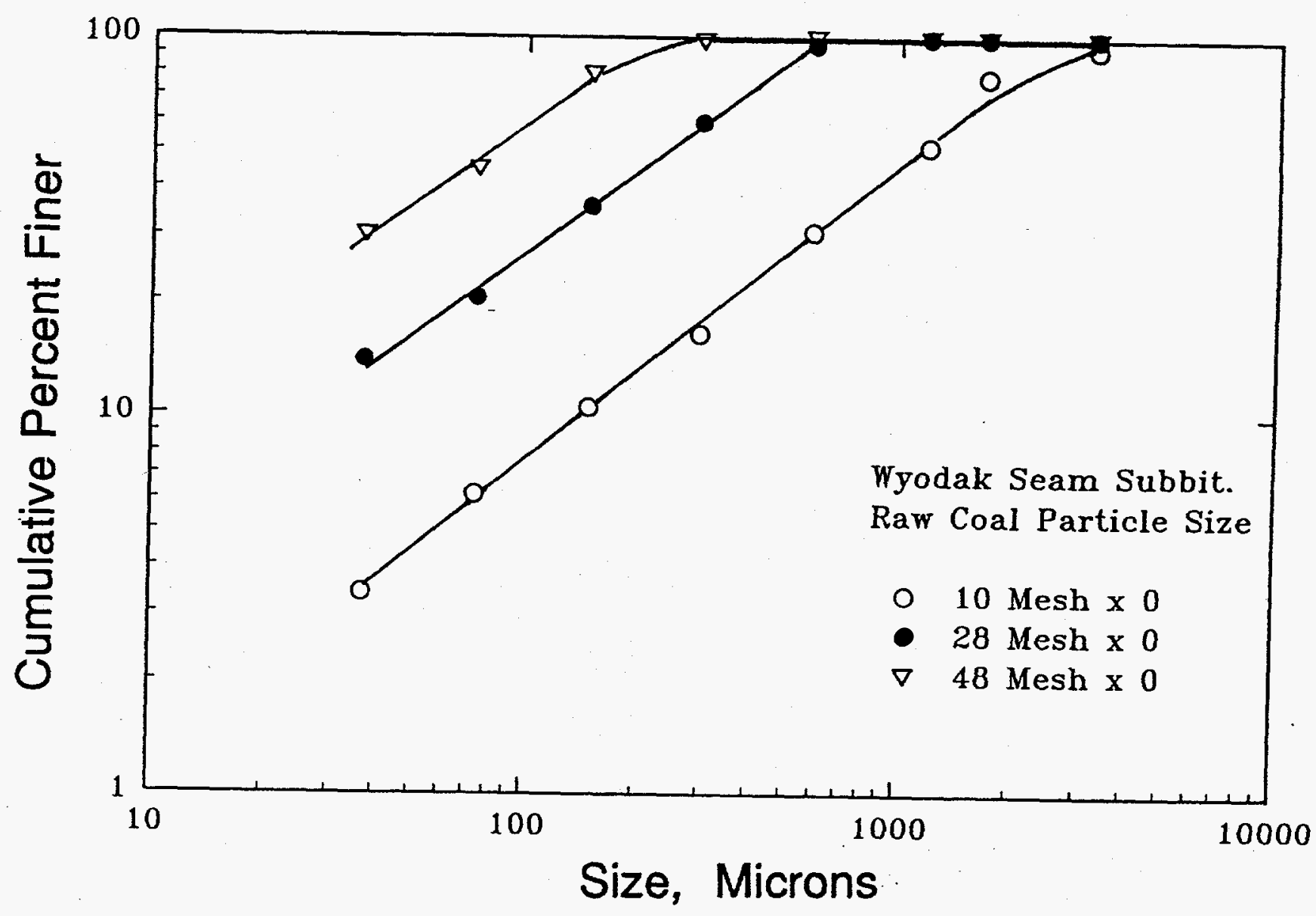

Figure 10. Particke Size Distribution of Wyodak Seam Subbituminous Raw Coal After Crushing. 


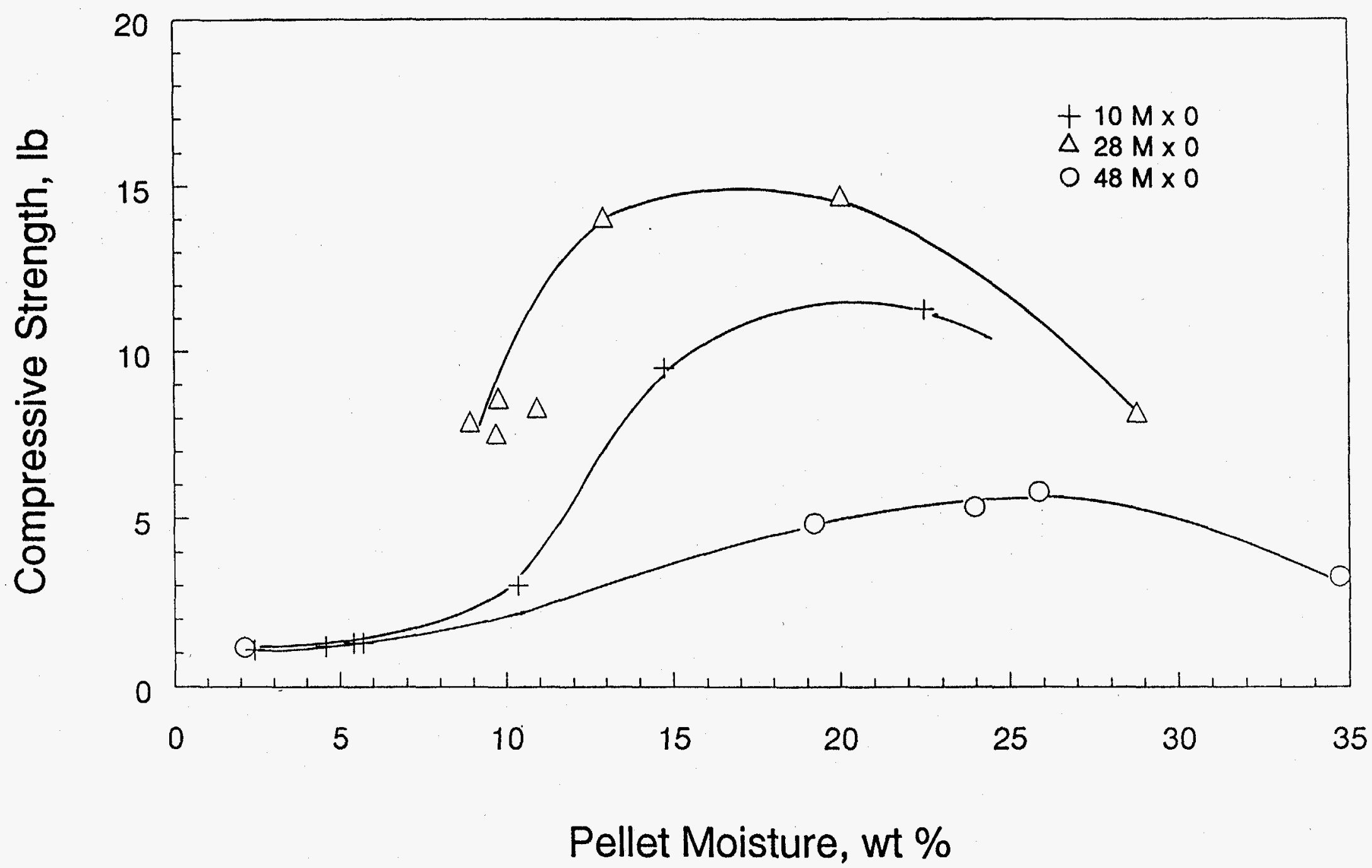

Figure 11. Effect of Feed Particle Size on Pellet Compressive Strength of Wyodak Subbituminous Raw Coal at 8 Weight \% CRS-2 Asphalt Emulsion. 


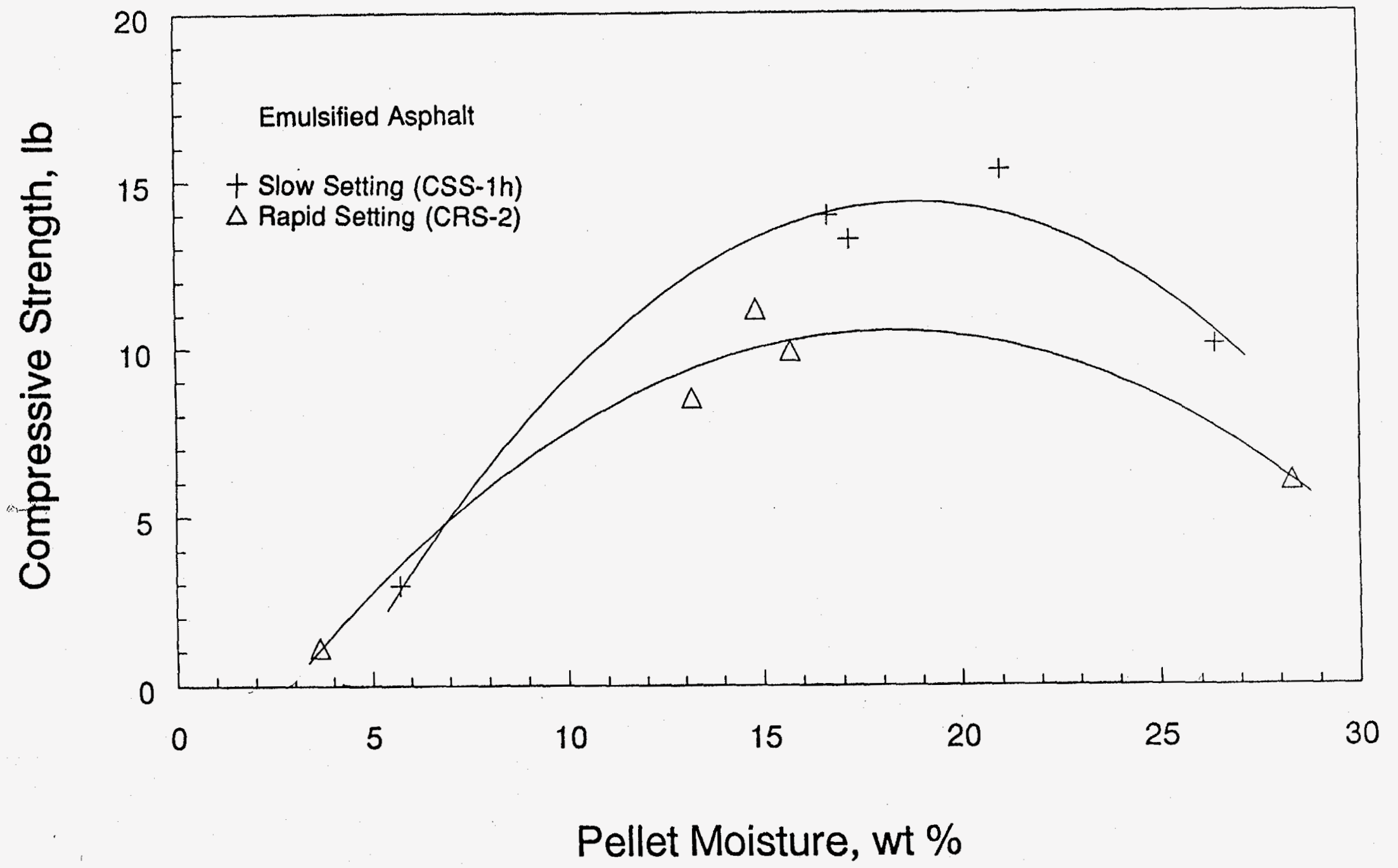

Figure 12. Effect of Emulsified Asphalt Types on Pellet Compressive Strength of Wyodak Subbituminous Raw Coal at 28 Mesh Top Size. 


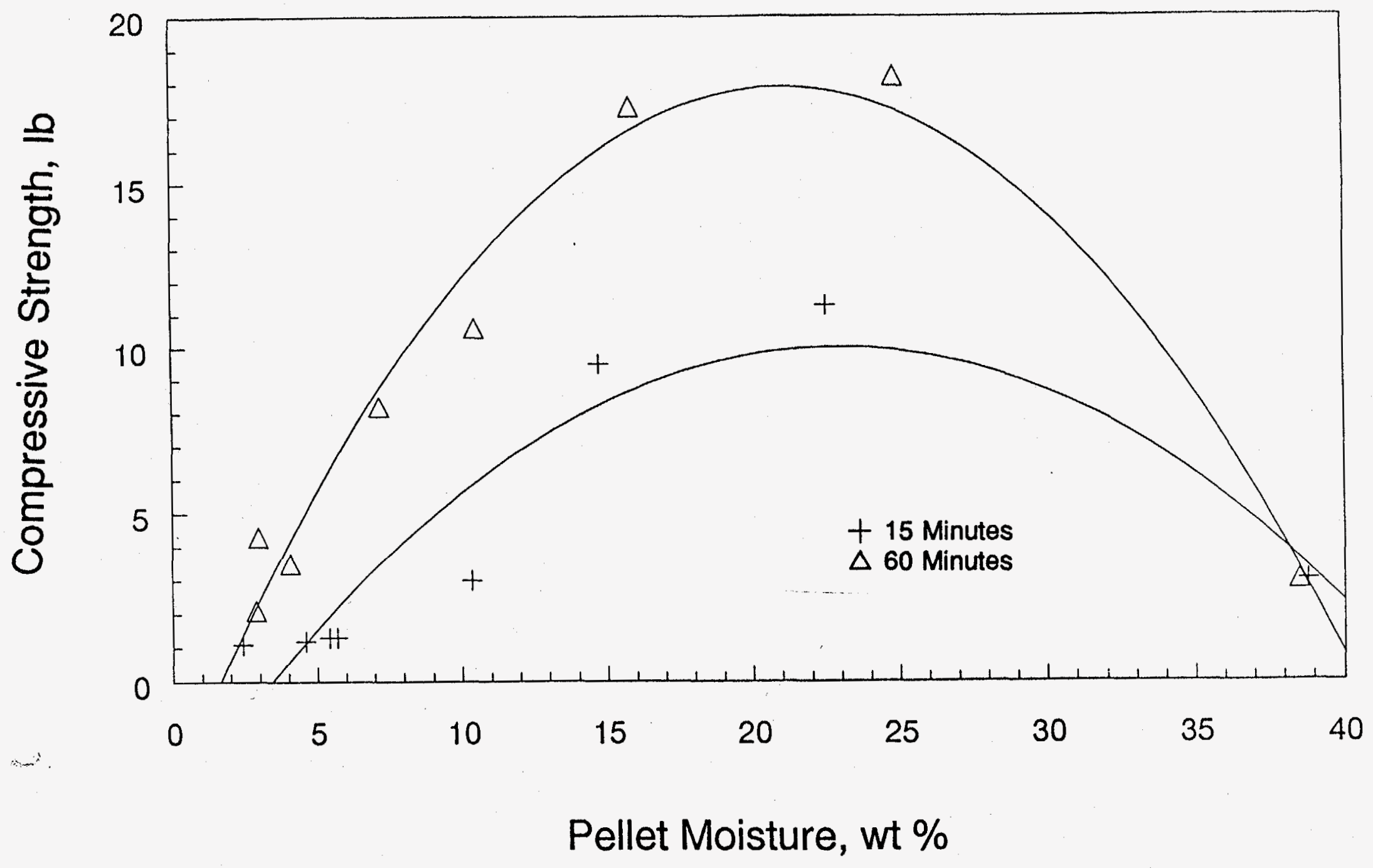

Figure 13. Effect of Mixing Time on Pellet Compressive Strength of Wyodak Subbituminous Coal at 10 Mesh Top Size with 8 Weight Percent Emulsified Asphalt (CRS-2). 


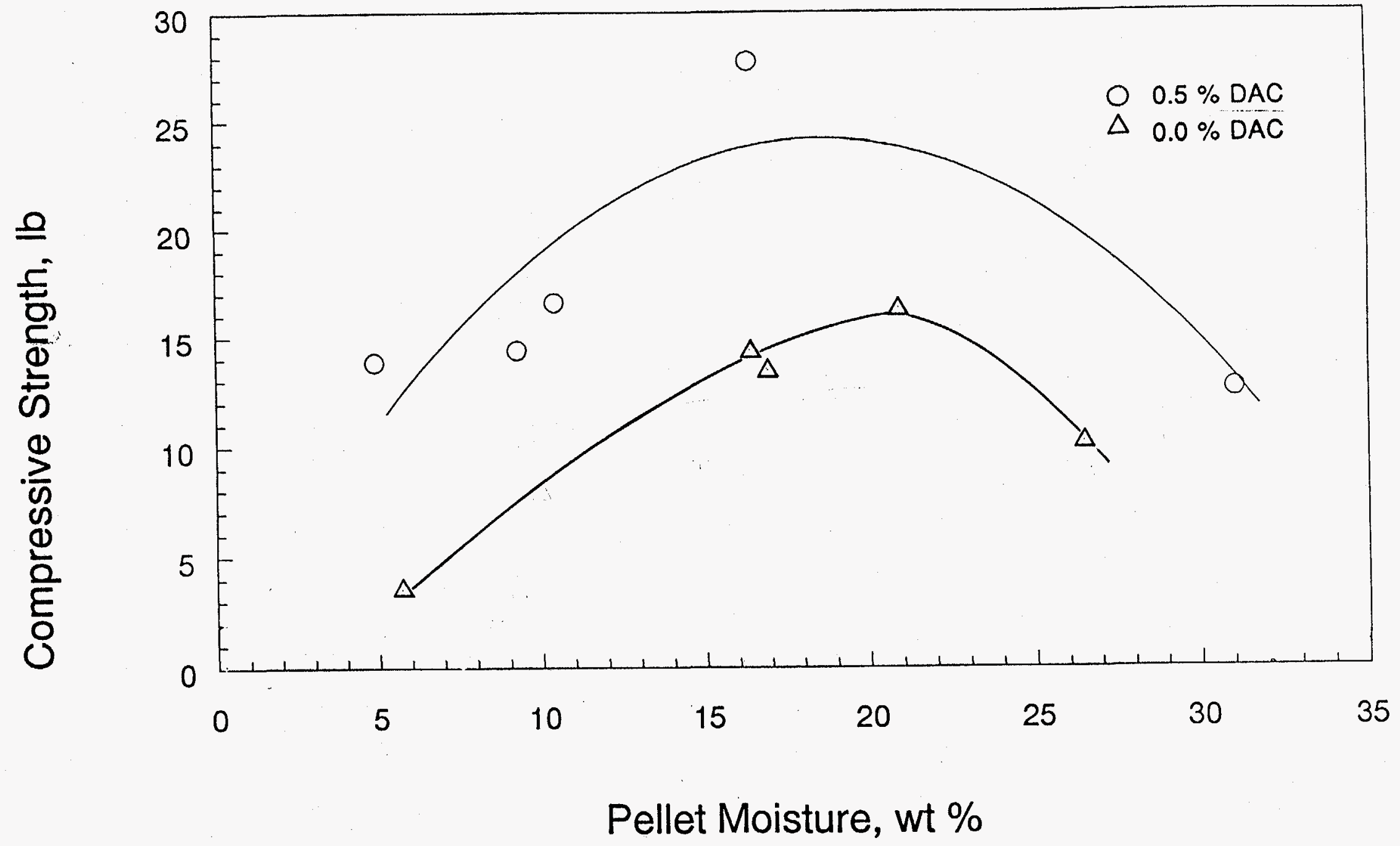

Figure 14. Effect of Surfactant Addition on Pellet Compressive Strength and Pellet Moisture Content of Wyodak Subbituminous Coal at 28 Mesh Top Size with 8 Weight Percent Emulsified Asphalt (CSS-1h). 


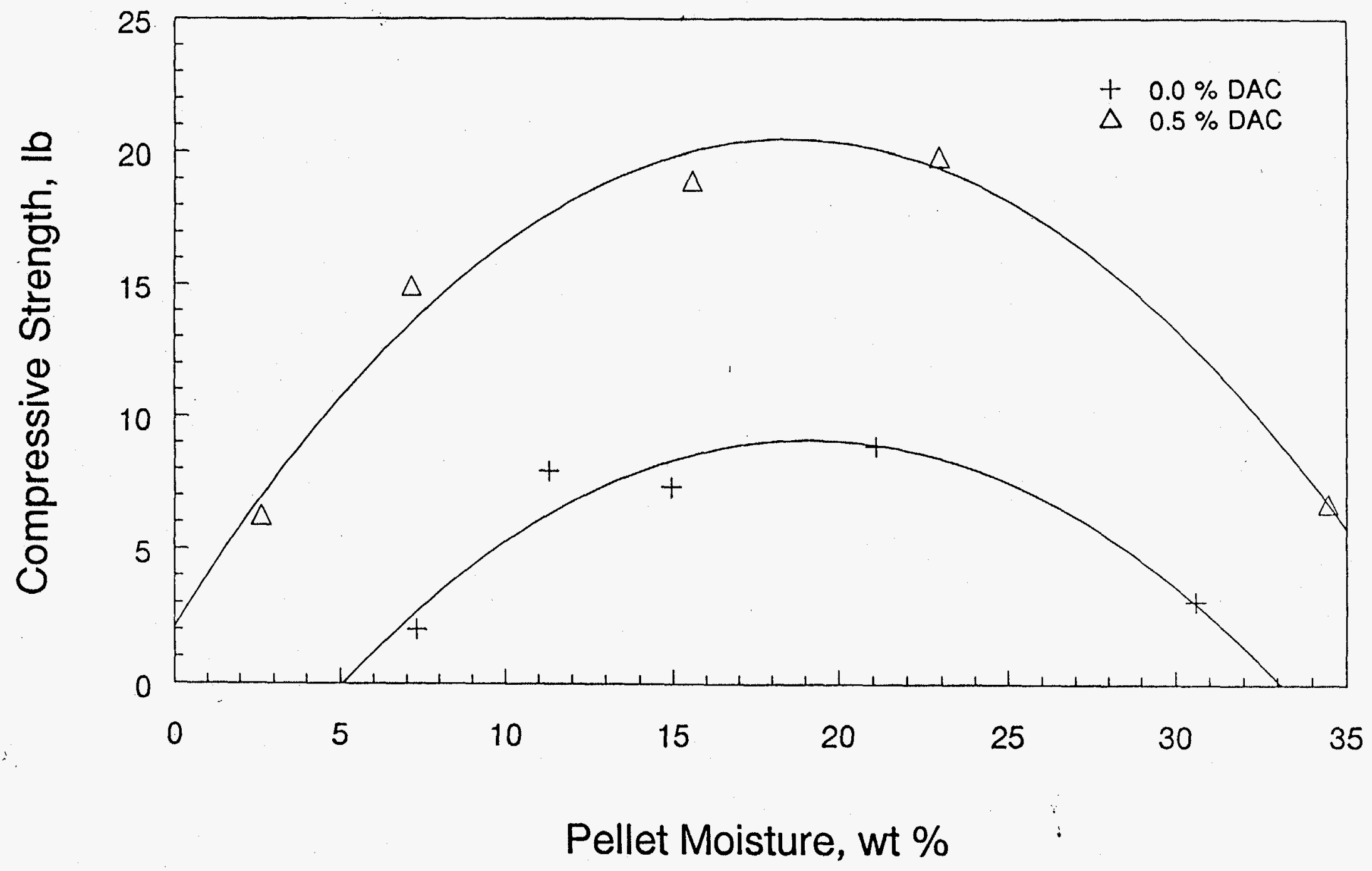

Figure 15. Effect of Surfactant Addition on Pellet Compressive Strength and Pellet Moisture Content of Wyodak Subbituminous Coal at 48 Mesh Top Size with 8 Weight Percent Emulsified Asphalt (CRS-2). 


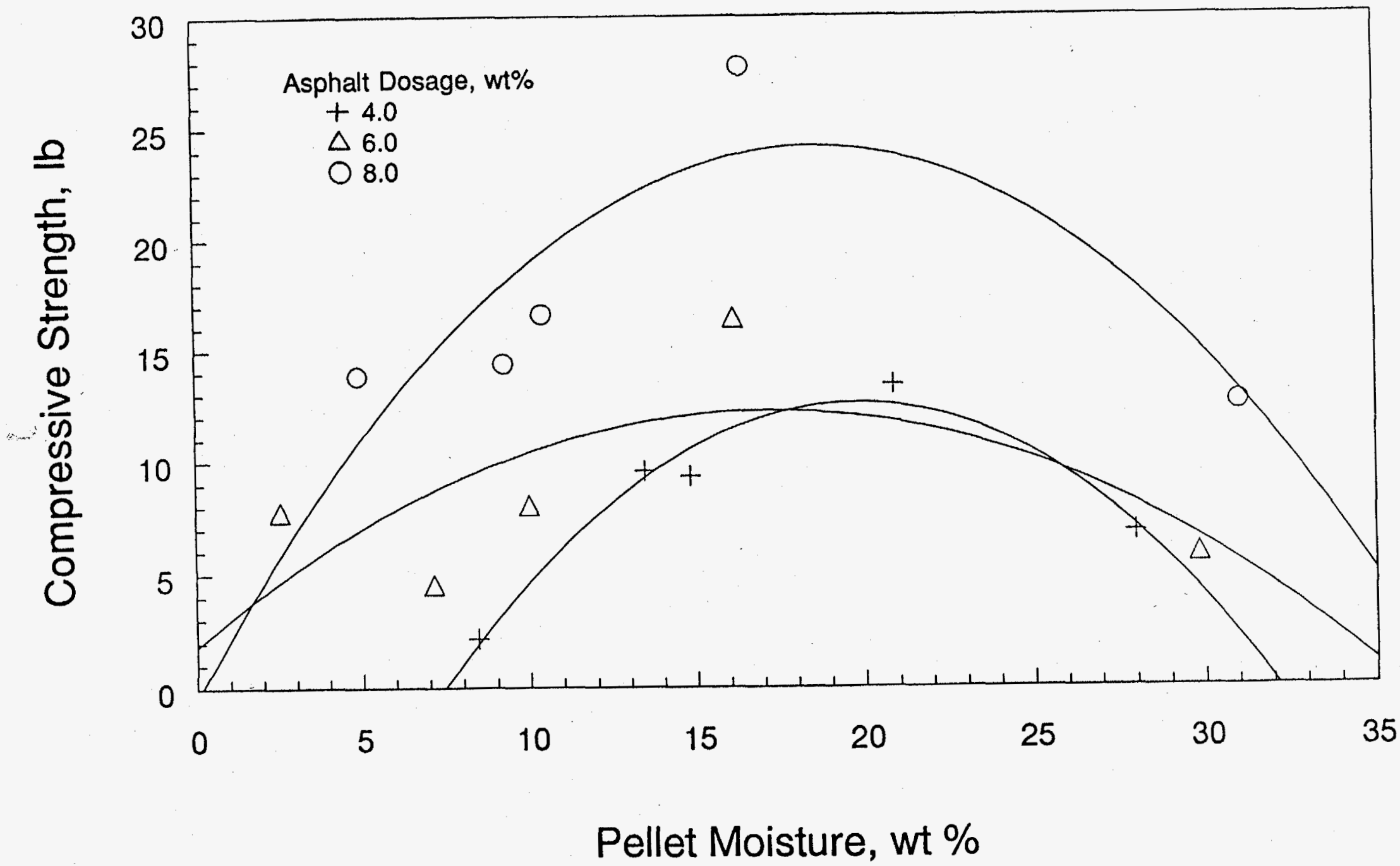

Figure 16. Effect of Asphalt (CSS-1h) Dosage on Pellet Compressive Strength and Pellet Moisture Content of Wyodak Subbituminous Coal (28 Mesh Top Size) with $0.5 \mathrm{lb} /$ Ton DAC Surfactant. 


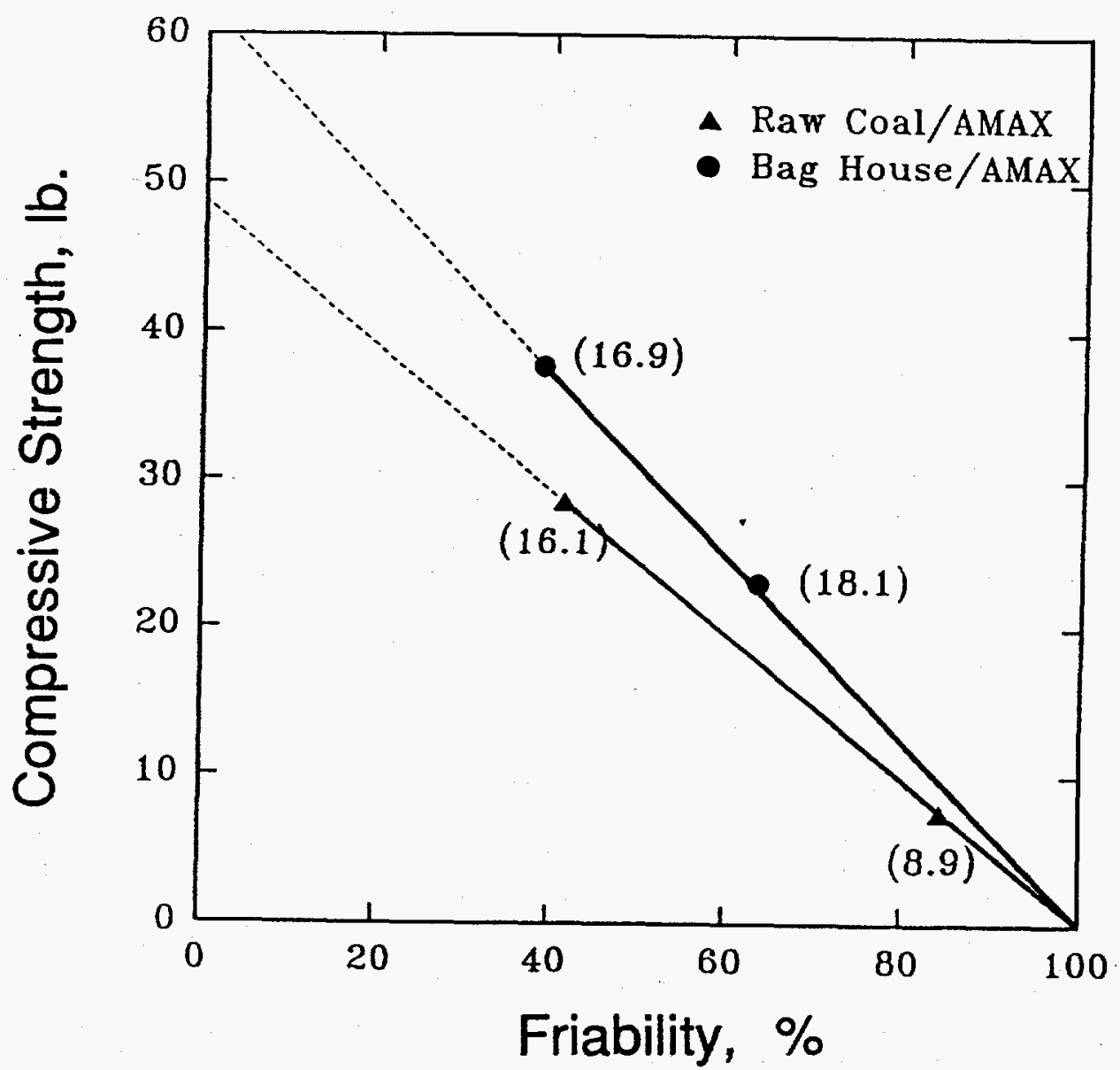

Figure 17. Correlation Between Pellet Fraibility and Strength for Subbituminous Raw Coal and Bag House Fines (Numbers in Parentheses are Moisture Contents). 
APPENDIX A

COOPERATIVE RESEARCH AND DEVELOPMENT AGREEMENT FOR A PROJECT BETWEEN PETC AND AMAX 


\section{COOPERATIVE RESEARCH AND DEVELOPMENT AGREEMENT FOR A PROJECT BETWEEN PETC AND AMAX}

$$
(1-8-1990)
$$

STATEMENT OF WORK

objective

The objective of this cooperative $R$ \& D Agreement is to produce, from fine subbituminous coal, economical reconstituted solid fuel forms that have suitable storage, handling, transportation, and combustion properties. The specific objectives of this agreement are: (1) to develop a humic acid binder from AMAX subbituminous coal using PETC-developed Humic Acid Binder Process, (2) to reconstitute AMAX's dried subbituminous coal fines from the bag house fine and the fluidized bed dryer product, (3) to produce lowmoisture, water-resistant pellets from raw subbituminous coal by the PETC-developed Lignipel Process, and (4) to produce 1-2 tons of reconstituted solid fuel for handleability and combustion tests.

\section{Background}

PETC has developed and patented a humic acid binder to reconstitute fine clean coal. The binder extracted from Leonardite has been successfully used in the reconstitution of fine bituminous coal. Some limited preliminary data on the application of humic acid binder for low rank coal pelletizing showed that pellets with satisfactory weather resistant properties could be developed. However, the pellets did not have adequate compressive strength. More research work should be conducted to improve the compressive strength of the pellets.

AMAX coal Industries Inc. is developing a fluidized-bed drying process to dry subbituminous coal from Wyoming from $30 \%$ moisture to $13 \%$. Currently, the dryer generates too many fines for proper transport and handling. About $80 \%$ of the dryer product is finer than 28 mesh, and about $10 \%$ of the dried coal is collected in the dryer bag house (minus 200 mesh). Paul woessner, Director of Research and Development of AMAX, met with personnel from PETC's Coal preparation Division and requested an investigation of the feasibility of applying the PETC's humic acid binder to reconstitute the bag house fines from the dryer. Mr. Woessner will serve as the AMAX project coordinator for this agreement, and Dr. George Wen of PETC's Coal Preparation Division will serve as the PETC project coordinator for this agreement.

\section{Work statement}

Task 1. PETC will supply the following to the cooperative agreement.

Subtask 1.1. Development of Humic Acid Binder From AMAX 


\section{Subbituminous coal.}

In this subtask, the coal samples (raw coal, dried coal, and bag house coal) received from AMAX will be characterized based on their proximate, ultimate, and surface analyses. The amount of alkali hydroxide extractable humic acids obtainable from these samples will be determined and will serve as a baseline for humic acid production development. The extraction of humic acids by ammonia will be examined and compared to the baseline.

To improve humic acid production, the coals will be subjected to dry or wet oxidation prior to extraction. Data from AMAX's drying experiments may be helpful in the development of these oxidation procedures.

Extraction procedures will emphasize the use of recyclable, cost efficient materials, or materials that will minimize the impact on the cost of the product. To accomplish this, modifications (such as pressure or temperature) to PETC's standard procedure will be explored.

This effort is being undertaken to demonstrate the viability of production of humic acid binder from Belle Ayr Mine coal. This technical feasibility study is expected to be completed within the first quarter of 1990 .

A final report on subtask 1.1 will be prepared within one month of the completion of work.

Subtask 1.2. Reconstitution of AMAX Subbituminous Coal by Humic Acid Binder.

In this subtask, the reconstitution of AMAX's dryer product and bag house fines with humic acid binder, extracted from Leonardite, will be performed in laboratory pelletizing and briquetting devices to determine the technical feasibility of those processes. Based on these results, a pelletizing or a briquetting process will be selected for the rest of the project.

To improve the compressive strength of the reconstituted product, variables such as binder dosage, drying time and temperature, final product moisture content, and feed moisture content should be tested. If a briquetting process is adopted, then the level of briquetting pressure should also be considered. Baseline tests will be performed on the bag house fines.

If a satisfactory reconstituted product can be developed by using humic acid binder extracted from Leonardite as mentioned above, then comparison tests should be performed by using the humic acid binder developed from the AMAX subbituminous coal (see subtask 1.1).

The laboratory feasibility study as mentioned above should be completed within the first quarter of 1990. A combined final 
report on the finding of subtask 1.1. and subtask 1.2. will be prepared within one month of the completion of work.

Subtask, 1.3. Application of the PETC Lignipel Process to AMAX Subbitumimous coal.

In this subtask PETC will apply the Lignipel process to raw Belle Ayr Mine Wyodok coal to produce low-moisture, water resistant pellets, with high compressive strength.

The key variables to be investigated include binder type (humic acid, asphalt) and dosage; feed particle size distribution; pellet feed moisture content; drying temperature, time, and rate; and final pellet moisture content.

This subtask should be completed around July of 1990, and a report will be prepared within one month of the completion of the work.

Task 2. AMAX will supply the following to the cooperative agreement.

AMAX's Research and Development Center will evaluate the physical properties of the reconstituted products, such as friability, dustiness, HGI, density, and chemical analyses. AMAX will also demonstrate the reconstitution process based on PETC's recommendation to produce a bulk quantity (1-2 tons) of product.

AMAX will deliver $1-2$ tons of the above reconstituted product (pellets or briquettes) to PETC for combustion tests in a warm-air furnace and in a cast-iron boiler by the Flue Gas cleanup Division. These combustion tests are not for this agreement but are part of PETC's in-house research program.

AMAX will provide travel expenses for up to 3 PETC personnel to visit their mine site, research center, and the fluidized dryer operation.

AMAX will provide funding of $\$ 25,000$ to PETC to offset about $1 / 2$ of the labor costs involved in PETC's three subtasks, a rough estimate of which is provided below:

Subtask 1.1

4 months of a Chemist working $75 \%$ of the time $=8.9 \mathrm{~K}$

4 months of a Chemist working $25 \%$ of the time $\quad=4.4 \mathrm{~K}$ Subtask 1.2

3 months of a Technician working at $50 \%$ of the time $=4.3 \mathrm{~K}$

3 months of an Engineer working at $50 \%$ of the time $=6.2 \mathrm{~K}$

4 months of a Project Leader working $35 \%$ of the time $=7.0 \mathrm{~K}$ Subtask 1.3

4 months of a Technician working $50 \%$ of the time $=5.6 \mathrm{~K}$

4 months of an Engineer working $50 \%$ of the time $=8.3 \mathrm{~K}$

4 months of a Project Leader working $35 \%$ of the time $=\frac{7.0 \mathrm{~K}}{51.7 \mathrm{~K}}$ 
APPENDIX B

SUBBITUMINOUS COAL PELLETIZING DATA 
AHAX COFL FRODLICTS TEST ING

\begin{tabular}{|c|c|c|c|c|c|c|c|c|c|c|c|c|c|c|}
\hline GIFTE & $\begin{array}{l}\text { TEST } \\
\text { NULM }\end{array}$ & $\begin{array}{r}\text { EINAER } \\
\text { T'HFE }\end{array}$ & $\begin{array}{l}\text { EIMD } \\
\text { HT } \\
\% \\
====\end{array}$ & $\begin{array}{l}\text { CHET } \\
\text { WGHT } \\
\text { FDDED } \\
====\end{array}$ & $\begin{array}{l}\text { COFL } \\
\text { TYFE } \\
\text { UISED } \\
\text { =ะ= = = }=\end{array}$ & $\begin{array}{l}\text { FEE[ } \\
\text { COAL. } \\
N 1 D I S T \\
====\end{array}$ & $\begin{array}{l}\text { DISC } \\
\text { FEED } \\
\text { MOIST } \\
=====\end{array}$ & $\begin{array}{l}\text { GREEN } \\
\text { PELLET } \\
\text { MOIST } \\
=====\end{array}$ & $\begin{array}{l}\text { QRY } \\
\text { TEMP } \\
\text { C }\end{array}$ & $\begin{array}{l}\text { CIRY } \\
\text { TIME E } \\
\text { MIN } \\
=:===\end{array}$ & $\begin{array}{l}\text { TEHP } \\
\text { GRADIENT } \\
\text { MOIST } \\
=======\end{array}$ & $\begin{array}{l}\text { DRIED } \\
\text { COHP } \\
\text { STRTH } \\
=====\end{array}$ & $\begin{array}{l}\text { HATER } \\
\text { UISINTE } \\
\quad \approx \\
=======\end{array}$ & 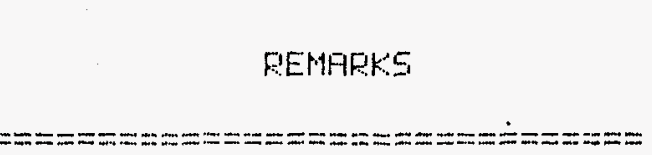 \\
\hline $\begin{array}{c}\text { DATE } \\
18-\mathrm{Apr}^{-}-90 \\
18-\mathrm{Ppr}^{-}-90 \\
18-\mathrm{FPr}^{-}-90 \\
18-\mathrm{Apr}-90\end{array}$ & $\begin{array}{c}\text { TEST } \\
1 \\
1 \\
1 \\
1\end{array}$ & $\begin{array}{c}\text { ET } \\
\text { ANMANHA } \\
\text { ANMAHA } \\
\text { AMMLHA } \\
\text { AMMAHA }\end{array}$ & $\begin{array}{r}\text { BW } \\
3 \\
3 \\
3 \\
3\end{array}$ & $\begin{array}{l}\text { CHEM } \\
\text { NORE } \\
\text { NORE } \\
\text { NORE } \\
\text { NONE }\end{array}$ & $\begin{array}{l}\text { COFIL } \\
\text { BAG HSE } \\
\text { BAG HSE } \\
\text { BAG HSE } \\
\text { EAG HSE }\end{array}$ & $\begin{array}{l}\text { FCH } \\
6.63 \\
6.63 \\
6.69 \\
6.63\end{array}$ & $\begin{array}{c}\text { QFH } \\
26.95 \\
26.95 \\
26.95 \\
26.95\end{array}$ & $\begin{array}{c}\text { GPN } \\
36.96 \\
36.96 \\
36.96 \\
36.96\end{array}$ & $\begin{array}{r}\text { ORY T } \\
6 \overline{2} \\
125 \\
160 \\
160\end{array}$ & $\begin{array}{c}\text { IDRY'M } \\
3 \overline{0} \\
54 \\
83 \\
111\end{array}$ & $\begin{array}{c}\text { GRFI M } \\
\text { inc } \\
\text { ine } \\
\text { inc } \\
\text { ine }\end{array}$ & $\begin{array}{c}\text { AUG_CS } \\
4.7 \\
4.9 \\
9.1 \\
3.9\end{array}$ & $\begin{array}{l}40 \\
100 \\
100 \\
100 \\
100\end{array}$ & 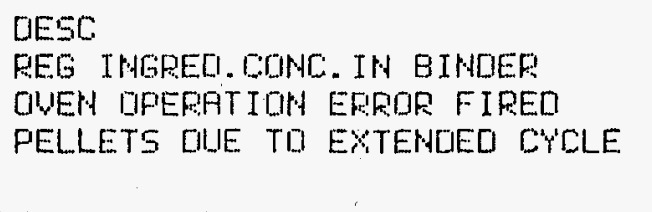 \\
\hline $\begin{array}{l}23-A p r-90 \\
23-A p r-90 \\
23-F p r-90 \\
23-F p r-90 \\
23-F p r-90 \\
23-F p r-90\end{array}$ & $\begin{array}{l}2 \\
2 \\
2 \\
2 \\
2 \\
2\end{array}$ & 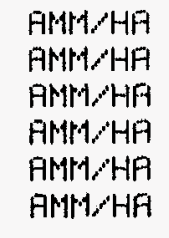 & $\begin{array}{l}3 \\
3 \\
3 \\
3 \\
3 \\
3\end{array}$ & $\begin{array}{l}\text { NOPE } \\
\text { MOP.E } \\
\text { MOPE } \\
\text { MONE } \\
\text { MOPE } \\
\text { NOPE }\end{array}$ & $\begin{array}{l}\text { BAG HSE } \\
\text { BAG HSE } \\
\text { BAG HSE } \\
\text { BAG HSE } \\
\text { BAG HSE } \\
\text { EAG HSE }\end{array}$ & $\begin{array}{l}6.63 \\
6.63 \\
6.63 \\
6.63 \\
6.63 \\
6.63\end{array}$ & $\begin{array}{l}40.14 \\
40.14 \\
40.14 \\
40.14 \\
40.14 \\
40.14\end{array}$ & $\begin{array}{l}37.45 \\
37.45 \\
37.45 \\
37.45 \\
37.45 \\
37.45\end{array}$ & $\begin{array}{r}62 \\
62 \\
62 \\
125 \\
150 \\
160\end{array}$ & $\begin{array}{r}10 \\
20 \\
30 \\
58 \\
104 \\
129\end{array}$ & $\begin{array}{l}\text { ine } \\
\text { inc } \\
\text { ine } \\
\text { ine } \\
\text { ine } \\
\text { inc }\end{array}$ & $\begin{array}{r}7 \\
1.8 \\
11.4 \\
13.6 \\
7.4\end{array}$ & $\begin{array}{l}100 \\
100 \\
100 \\
100 \\
100 \\
100\end{array}$ & 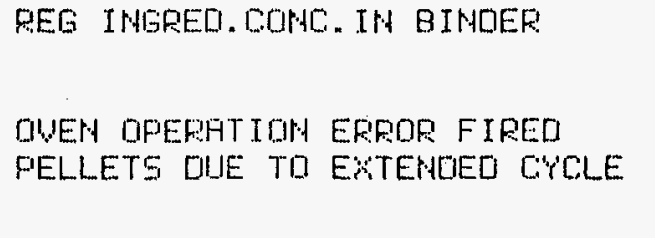 \\
\hline $\begin{array}{l}24-A p r-90 \\
24-A p r-90 \\
24-A p r-90 \\
24-A p r-901 \\
24-7 p r-90 \\
24-A p r-90 \\
24-F p r-90\end{array}$ & $\begin{array}{l}3 \\
3 \\
3 \\
3 \\
3 \\
3 \\
3\end{array}$ & 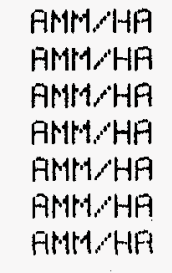 & $\begin{array}{l}5 \\
6 \\
6 \\
E \\
6 \\
E \\
E\end{array}$ & $\begin{array}{l}\text { MOLE } \\
\text { MOPE } \\
\text { NOPE } \\
\text { NOPE } \\
\text { MOPE } \\
\text { MOPE } \\
\text { MORE }\end{array}$ & $\begin{array}{ll}\text { BAG } & H S E \\
\text { EAG } & H S E \\
\text { BAG } & H S E \\
\text { BAG } & \text { HSE } \\
\text { EAGG } & \text { HSE } \\
\text { BAG } & \text { HSE } \\
\text { BAG } & \text { HSE }\end{array}$ & $\begin{array}{l}6.63 \\
6.63 \\
6.63 \\
6.63 \\
6.63 \\
6.63 \\
6.63\end{array}$ & $\begin{array}{l}35.74 \\
35.74 \\
35.74 \\
35.74 \\
35.74 \\
35.74 \\
35.74\end{array}$ & $\begin{array}{l}37.72 \\
37.72 \\
37.72 \\
37.72 \\
37.72 \\
37.72 \\
37.72\end{array}$ & $\begin{array}{r}62 \\
62 \\
62 \\
125 \\
140 \\
140 \\
140\end{array}$ & $\begin{array}{r}10 \\
20 \\
30 \\
58 \\
90 \\
120 \\
150\end{array}$ & $\begin{array}{r}35.9 \\
34.43 \\
31.2 \\
25.09 \\
9.44 \\
2.66 \\
\text { ine }\end{array}$ & $\begin{array}{r}5.7 \\
9.1 \\
9.2 \\
15.1 \\
12.5 \\
9.63 \\
7\end{array}$ & $\begin{array}{l}100 \\
100 \\
100 \\
100 \\
100 \\
100 \\
100\end{array}$ & EEG IHGRED. COHA. IN BIMOEF! \\
\hline $\begin{array}{l}26-\mathrm{Apr}-90 \\
26-\mathrm{Hpr}-90 \\
26-\mathrm{F} \text { Fr }-90 \\
26-\mathrm{Fpr}-90\end{array}$ & $\begin{array}{l}4 \\
4 \\
4 \\
4\end{array}$ & $\begin{array}{l}\text { ANHAHA } \\
\text { AMINHA } \\
\text { AMHLHA } \\
\text { AMPLHA }\end{array}$ & $\begin{array}{l}4.5 \\
4.5 \\
4.5 \\
4.5\end{array}$ & $\begin{array}{l}\text { MOHE } \\
\text { MOHE } \\
\text { MOHE } \\
\text { MORE }\end{array}$ & $\begin{array}{ll}\text { EAG } & \text { HSE } \\
\text { BAG } & \text { HSE } \\
\text { BAG } & \text { HSE } \\
\text { BAG } & \text { HSE }\end{array}$ & $\begin{array}{l}6.63 \\
6.63 \\
6.63 \\
6.63\end{array}$ & $\begin{array}{l}\text { inc } \\
\text { inc } \\
\text { ins } \\
\text { inc }\end{array}$ & $\begin{array}{l}37.72 \\
37.72 \\
37.72 \\
37.72\end{array}$ & $\begin{array}{l}62 \\
125 \\
125 \\
125\end{array}$ & $\begin{array}{l}30 \\
54 \\
74 \\
84\end{array}$ & $\begin{array}{l}\text { ine } \\
\text { ine } \\
\text { ine } \\
\text { ine }\end{array}$ & $\begin{array}{r}11.6 \\
11.5 \\
10.2 \\
5.5\end{array}$ & $\begin{array}{l}100 \\
100 \\
100 \\
100\end{array}$ & REE IHGPECI. COHWC. IH BIHDEF \\
\hline $\begin{array}{l}26-A p r-90 \\
26-F p r-90 \\
26-F p r-90 \\
26-F p r-90\end{array}$ & $\begin{array}{l}4-A \\
4-A \\
4-A \\
4-A\end{array}$ & $\begin{array}{l}\text { ANH1 HA } \\
\text { AHNDHA } \\
\text { ANHWHA } \\
\text { ANHLHA }\end{array}$ & $\begin{array}{l}4.5 \\
4.5 \\
4.5 \\
4.5\end{array}$ & $\begin{array}{l}\text { MORE } \\
\text { NOPE } \\
\text { NORE } \\
\text { MORE }\end{array}$ & $\begin{array}{ll}\text { BAG } & H S E \\
\text { BAG } & H S E \\
\text { BAG } & H S E \\
\text { BAG } & H S E\end{array}$ & $\begin{array}{l}6.63 \\
6.63 \\
6.63 \\
6.63\end{array}$ & $\begin{array}{l}35.74 \\
35.74 \\
35.74 \\
35.74\end{array}$ & $\begin{array}{l}37.72 \\
37.72 \\
37.72 \\
37.72\end{array}$ & $\begin{array}{l}62 \\
125 \\
125 \\
125\end{array}$ & $\begin{array}{l}30 \\
54 \\
74 \\
84\end{array}$ & $\begin{array}{l}\text { inc } \\
\text { inc } \\
\text { inc } \\
\text { inc }\end{array}$ & $\begin{array}{l}14.7 \\
14.7 \\
18.5 \\
15.5\end{array}$ & $\begin{array}{l}100 \\
100 \\
100 \\
100\end{array}$ & 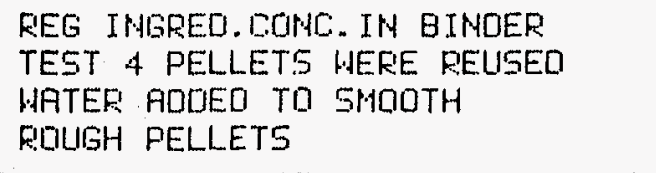 \\
\hline 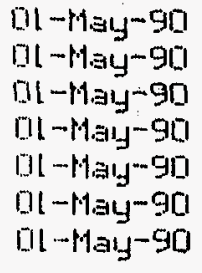 & $\begin{array}{r}5 \\
5 \\
5 \\
5 \\
5 \\
5 \\
5\end{array}$ & 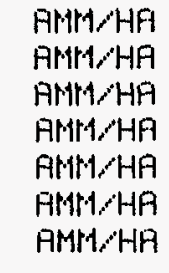 & $\begin{array}{l}4.5 \\
4.5 \\
4.5 \\
4.5 \\
4.5 \\
4.5 \\
4.5\end{array}$ & $\begin{array}{l}\text { MOPE } \\
\text { NORE } \\
\text { MORE } \\
\text { MORE } \\
\text { MORE } \\
\text { MORE } \\
\text { MORE }\end{array}$ & $\begin{array}{ll}\text { BAG } & H S E \\
\text { BAG } & H S E \\
\text { BAG } & H S E \\
\text { BAG } & H S E \\
\text { BAG } & H S E \\
\text { BAG } & \text { HSE } \\
\text { BAG } & H S E\end{array}$ & $\begin{array}{l}6.63 \\
6.63 \\
6.63 \\
6.63 \\
6.63 \\
6.63 \\
6.63\end{array}$ & $\begin{array}{l}36.17 \\
36.17 \\
36.17 \\
36.17 \\
36.17 \\
36.17 \\
36.17\end{array}$ & $\begin{array}{l}37.5 \\
37.5 \\
37.5 \\
37.5 \\
37.5 \\
37.5 \\
37.5\end{array}$ & $\begin{array}{l}62 \\
125 \\
150 \\
160 \\
170 \\
180 \\
190\end{array}$ & $\begin{array}{r}30 \\
50 \\
73 \\
88 \\
92 \\
96 \\
100\end{array}$ & $\begin{array}{r}25.54 \\
16.18 \\
6.56 \\
1.88 \\
4.99 \\
1.79 \\
2.9\end{array}$ & $\begin{array}{r}17.15 \\
12.05 \\
5.97 \\
3.2 \\
5.49 \\
4.28 \\
4.13\end{array}$ & $\begin{array}{l}100 \\
100 \\
100 \\
100 \\
100 \\
100 \\
100\end{array}$ & \\
\hline
\end{tabular}


AMAK COAL FROCIUCTS TESTING

\begin{tabular}{|c|c|c|c|c|c|c|c|c|c|c|c|c|c|c|}
\hline OHTE & $\begin{array}{l}\text { TEST } \\
\text { NUM }\end{array}$ & $\begin{array}{c}\text { EINCIER } \\
\text { THFE }\end{array}$ & 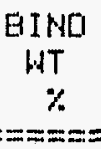 & $\begin{array}{l}\text { CHEM } \\
\text { WGHT } \\
\text { RODED } \\
==\end{array}$ & $\begin{array}{c}\text { COFL } \\
\text { TYPE } \\
\text { USED } \\
======\end{array}$ & $\begin{array}{l}\text { FEED } \\
\text { CDAL } \\
\text { MOIST } \\
====\end{array}$ & $\begin{array}{l}\text { DISC } \\
\text { FEED } \\
\text { MDIST } \\
=== \pm=\end{array}$ & $\begin{array}{l}\text { GREEN } \\
\text { PELLET } \\
\text { MOIST } \\
== \pm===\end{array}$ & $\begin{array}{c}\text { DRY } \\
\text { TEMP } \\
\text { C } \\
=====\end{array}$ & $\begin{array}{l}\text { ORY } \\
\text { TINE E } \\
\text { MIN } \\
== \pm===\end{array}$ & $\begin{array}{c}\text { TEMP } \\
\text { GRADIENT } \\
\text { MOIST } \\
== \pm===\end{array}$ & $\begin{array}{l}\text { DRIED } \\
\text { CUMP D } \\
\text { STRTH } \\
=== \pm==\end{array}$ & $\begin{array}{c}\text { HATER } \\
\text { UISINTE } \\
\% \\
=======\end{array}$ & 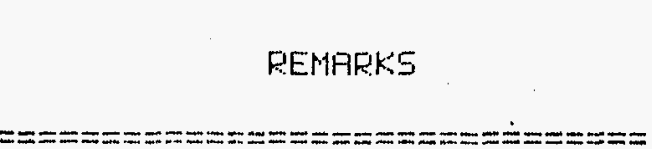 \\
\hline DATTE & TEST & ET & Bn. & CHEM & COFIL & FCM & DFM & GPM & DRY 1 & TORY ...M & GRAD M & AWG_CS & $\quad 40$ & CJESC \\
\hline $\begin{array}{l}17 p-1 a y-90 \\
07-1 a y-90 \\
07-1 a y-9[1 \\
07-1 a y-901 \\
07-1 a y-90 \\
07-1 a y-90\end{array}$ & $\begin{array}{l}6 \\
6 \\
6 \\
6 \\
6 \\
6\end{array}$ & 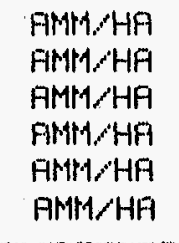 & $\begin{array}{l}9.0 \\
9.0 \\
9.0 \\
9.0 \\
9.0 \\
9.0\end{array}$ & $\begin{array}{l}\text { NONE } \\
\text { NONE } \\
\text { MONE } \\
\text { NONE } \\
\text { NONE } \\
\text { NONE }\end{array}$ & $\begin{array}{l}\text { BAG HSE } \\
\text { BAG HSE } \\
\text { BAG HSE } \\
\text { BAG HSE } \\
\text { BAG HSE } \\
\text { BAG HSE }\end{array}$ & $\begin{array}{l}6.63 \\
6.63 \\
6.63 \\
6.63 \\
6.63 \\
6.63\end{array}$ & $\begin{array}{l}36.43 \\
36.43 \\
36.43 \\
36.43 \\
36.43 \\
36.43\end{array}$ & $\begin{array}{l}38.38 \\
38.38 \\
38.38 \\
38.38 \\
38.38 \\
38.38\end{array}$ & $\begin{array}{r}62 \\
125 \\
150 \\
160 \\
170 \\
180\end{array}$ & $\begin{array}{l}30 \\
46 \\
53 \\
56 \\
62 \\
66\end{array}$ & $\begin{array}{r}30.65 \\
21.42 \\
17 \\
14.37 \\
14.71 \\
10.18\end{array}$ & $\begin{array}{l}12.1 \\
11.9 \\
9.7 \\
12.1 \\
3.1 \\
3.0\end{array}$ & $\begin{array}{l}100 \\
100 \\
100 \\
100 \\
100 \\
100\end{array}$ & \\
\hline $\begin{array}{l}08-1 a y-90 \\
019-1 a y-90 \\
019-1 a y-90 \\
010-1 a y-90 \\
019-1 a y-90 \\
08-1 a y-90 \\
010-1 a y-90\end{array}$ & $\begin{array}{l}7 \\
7 \\
7 \\
7 \\
7 \\
7 \\
7\end{array}$ & $\begin{array}{l}\text { LOSTEH } \\
\text { LDSTRH } \\
\text { LDSTEHH } \\
\text { LOSTRH } \\
\text { LDSTRH } \\
\text { LDSTEH } \\
\text { LDSTRH }\end{array}$ & $\begin{array}{l}6.0 \\
6.0 \\
6.0 \\
6.0 \\
6.0 \\
6.0 \\
6.0\end{array}$ & $\begin{array}{l}\text { NOPE } \\
\text { NORE } \\
\text { NORE } \\
\text { MOPE } \\
\text { MOPE } \\
\text { NOTE } \\
\text { NORE }\end{array}$ & $\begin{array}{ll}\text { BAG } & H S E \\
\text { BAG } & H S E \\
\text { BAG } & H S E \\
\text { BAG } & \text { HSE } \\
\text { BAG } & \text { HSE } \\
\text { BAG } & \text { HSE } \\
\text { EAG } & \text { HSE }\end{array}$ & $\begin{array}{l}6.63 \\
6.63 \\
6.63 \\
6.63 \\
6.63 \\
6.63 \\
6.63\end{array}$ & $\begin{array}{l}34.34 \\
34.34 \\
34.34 \\
34.34 \\
34.34 \\
34.34 \\
34.34\end{array}$ & $\begin{array}{l}35.05 \\
35.05 \\
35.05 \\
35.05 \\
35.05 \\
35.05 \\
35.05\end{array}$ & $\begin{array}{r}62 \\
125 \\
150 \\
160 \\
170 \\
180 \\
190\end{array}$ & $\begin{array}{l}30 \\
44 \\
54 \\
60 \\
65 \\
70 \\
75\end{array}$ & $\begin{array}{l}26.17 \\
19.61 \\
14.58 \\
11.11 \\
11.79 \\
10.74 \\
=\end{array}$ & $\begin{array}{r}16.11 \\
19.91 \\
14.31 \\
20.41 \\
11.11 \\
11.91 \\
7.02\end{array}$ & $\begin{array}{r}100 \\
50 \\
40 \\
30 \\
50 \\
0 \\
0\end{array}$ & COHICOI LIDUIO STFRCH BIHDER \\
\hline $\begin{array}{l}10-M a y-90 \\
10-1 . y-90 \\
10-1 . a y-90 \\
10-1 . a y-90 \\
10-1 . a y-90 \\
10-1 a y-90 \\
10-13 y-90\end{array}$ & $\begin{array}{l}9 \\
\theta \\
日 \\
8 \\
8 \\
\theta \\
8\end{array}$ & $\begin{array}{l}\text { AEPHAHLT } \\
\text { AEPHFILT } \\
\text { ASPHALT } \\
\text { ASPHALTT } \\
\text { FSPHFLT } \\
\text { FSPHFLT } \\
\text { ASPHALT }\end{array}$ & $\begin{array}{l}\text { B. } \\
\text { a.0 } \\
\text { 日. } \\
\text { ब. } \\
\text { 日. } \\
\text { 日. } \\
\text { 日. }\end{array}$ & $\begin{array}{l}\text { MOPE } \\
\text { NOPE } \\
\text { NORE } \\
\text { MOPE } \\
\text { NOPE } \\
\text { NOPE } \\
\text { NOPE }\end{array}$ & $\begin{array}{l}\text { BAS } \text { HSE } \\
\text { BAG HSE } \\
\text { EAG HSE } \\
\text { BAG HSE } \\
\text { EAG HSE } \\
\text { BAG HSE } \\
\text { BAG HSE }\end{array}$ & $\begin{array}{l}6.63 \\
6.63 \\
6.63 \\
E .63 \\
6.63 \\
6.63 \\
6.63\end{array}$ & $\begin{array}{l}36.43 \\
36.43 \\
36.43 \\
36.43 \\
36.43 \\
36.43 \\
36.43\end{array}$ & $\begin{array}{l}38.38 \\
38.39 \\
38.39 \\
38.38 \\
38.38 \\
38.38 \\
38.38\end{array}$ & $\begin{array}{l}62 \\
125 \\
150 \\
160 \\
170 \\
180 \\
190\end{array}$ & $\begin{array}{l}30 \\
43 \\
52 \\
57 \\
60 \\
64 \\
68\end{array}$ & $\begin{array}{r}23.73 \\
21.18 \\
17.36 \\
13.81 \\
8.49 \\
10.89 \\
10.95\end{array}$ & $\begin{array}{r}17.91 \\
20.91 \\
21.31 \\
19.11 \\
10.31 \\
9.21 \\
14.61\end{array}$ & $\begin{array}{l}0 \\
0 \\
0 \\
0 \\
0 \\
0 \\
0\end{array}$ & CASS HSPHFLT EM. BIMDER \\
\hline $\begin{array}{l}15-M a y-90 \\
15-M a y-90 \\
15-M a y-90 \\
15-1 a y-90 \\
15-M a y-90 \\
15-M a y-90 \\
15-M a y-90\end{array}$ & $\begin{array}{l}9 \\
9 \\
9 \\
9 \\
9 \\
9 \\
9\end{array}$ & 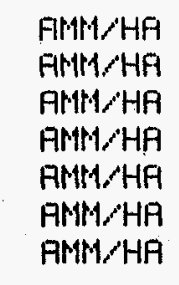 & $\begin{array}{l}4.5 \\
4.5 \\
4.5 \\
4.5 \\
4.5 \\
4.5 \\
4.5\end{array}$ & $\begin{array}{l}\text { NOPE } \\
\text { NORE } \\
\text { NOPE } \\
\text { MONE } \\
\text { NONE } \\
\text { MONE } \\
\text { NONE }\end{array}$ & $\begin{array}{ll}\text { BAG } & \text { HSE } \\
\text { BAG } & \text { HSE } \\
\text { BAG } & \text { HSE } \\
\text { BAG HSE } \\
\text { BAG HSE } \\
\text { BAG HSE } \\
\text { BAG HSE }\end{array}$ & $\begin{array}{l}6.63 \\
6.63 \\
6.63 \\
6.63 \\
6.63 \\
6.63 \\
6.63\end{array}$ & $\begin{array}{l}38.5 \\
38.5 \\
38.5 \\
38.5 \\
38.5 \\
38.5 \\
38.5\end{array}$ & $\begin{array}{l}36.79 \\
36.79 \\
36.79 \\
36.79 \\
36.79 \\
36.79 \\
36.79\end{array}$ & $\begin{array}{r}62 \\
125 \\
150 \\
160 \\
170 \\
180 \\
190\end{array}$ & $\begin{array}{l}30 \\
41 \\
48 \\
52 \\
56 \\
60 \\
65\end{array}$ & $\begin{array}{l}27.04 \\
25.83 \\
17.99 \\
17.87 \\
19.11 \\
11.06 \\
10.96\end{array}$ & $\begin{array}{l}16.31 \\
18.51 \\
21.41 \\
22.71 \\
19.71 \\
14.71 \\
11.41\end{array}$ & $\begin{array}{l}100 \\
100 \\
100 \\
100 \\
100 \\
100 \\
100\end{array}$ & REPEAT AKNM1, HF BIHDER \\
\hline $\begin{array}{l}21-M a y-90 \\
21-M a y-90 \\
21-M a y-90 \\
21-M a y-90 \\
21-M a y-90 \\
21-M a y-90 \\
21-M a y-90\end{array}$ & $\begin{array}{l}10 \\
10 \\
10 \\
10 \\
10 \\
10 \\
10\end{array}$ & $\begin{array}{l}\text { ASPHALT } \\
\text { ASPHALT } \\
\text { ASPHALT } \\
\text { ASPHALT } \\
\text { ASPHFLT } \\
\text { ASPHALT } \\
\text { ASPHALT }\end{array}$ & $\begin{array}{l}\text { B. } \\
\text { B. } \\
\text { 日. } \\
8.0 \\
\text { B. } \\
\text { B. } \\
\text { B. }\end{array}$ & $\begin{array}{l}\text { NORE } \\
\text { NONE } \\
\text { MONE } \\
\text { MOPE } \\
\text { NONE } \\
\text { MONE } \\
\text { NONE }\end{array}$ & $\begin{array}{l}\text { RAW COAL } \\
\text { RAW COOAL } \\
\text { RAW COAL } \\
\text { RAW COAL } \\
\text { RAW COAL } \\
\text { RAW COAL } \\
\text { RAW COAL }\end{array}$ & $\begin{array}{l}13.67 \\
13.67 \\
13.67 \\
13.67 \\
13.67 \\
13.67 \\
13.67\end{array}$ & $\begin{array}{l}37.26 \\
37.26 \\
37.26 \\
37.26 \\
37.26 \\
37.26 \\
37.26\end{array}$ & $\begin{array}{l}38.84 \\
38.84 \\
38.84 \\
38.84 \\
38.84 \\
38.84 \\
38.84\end{array}$ & $\begin{array}{l}62 \\
125 \\
150 \\
160 \\
170 \\
180 \\
190\end{array}$ & $\begin{array}{l}30 \\
46 \\
54 \\
60 \\
63 \\
67 \\
73\end{array}$ & $\begin{array}{r}22.49 \\
14.73 \\
10.34 \\
5.68 \\
4.56 \\
5.41 \\
2.41\end{array}$ & $\begin{array}{r}11.3 \\
9.51 \\
3 \\
1.3 \\
1.2 \\
1.3 \\
1.1\end{array}$ & $\begin{array}{l}0 \\
0 \\
0 \\
0 \\
0 \\
0 \\
0\end{array}$ & CRS FIPHFLT EM. EIMIDER \\
\hline
\end{tabular}


AHAK COAL PRODIUCTS TEST IHG

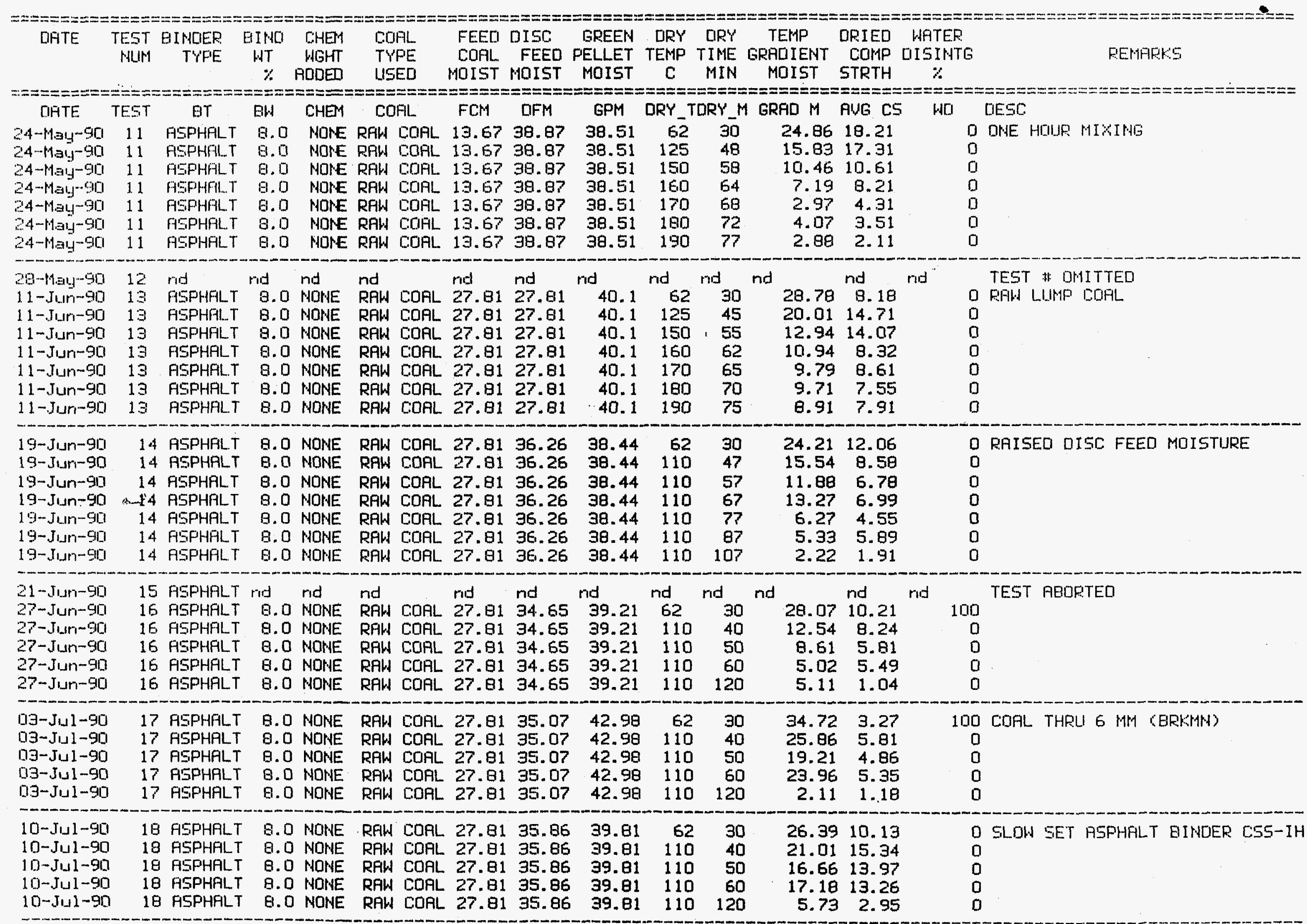


PMAX COFHL FROCIICTS TEST ING

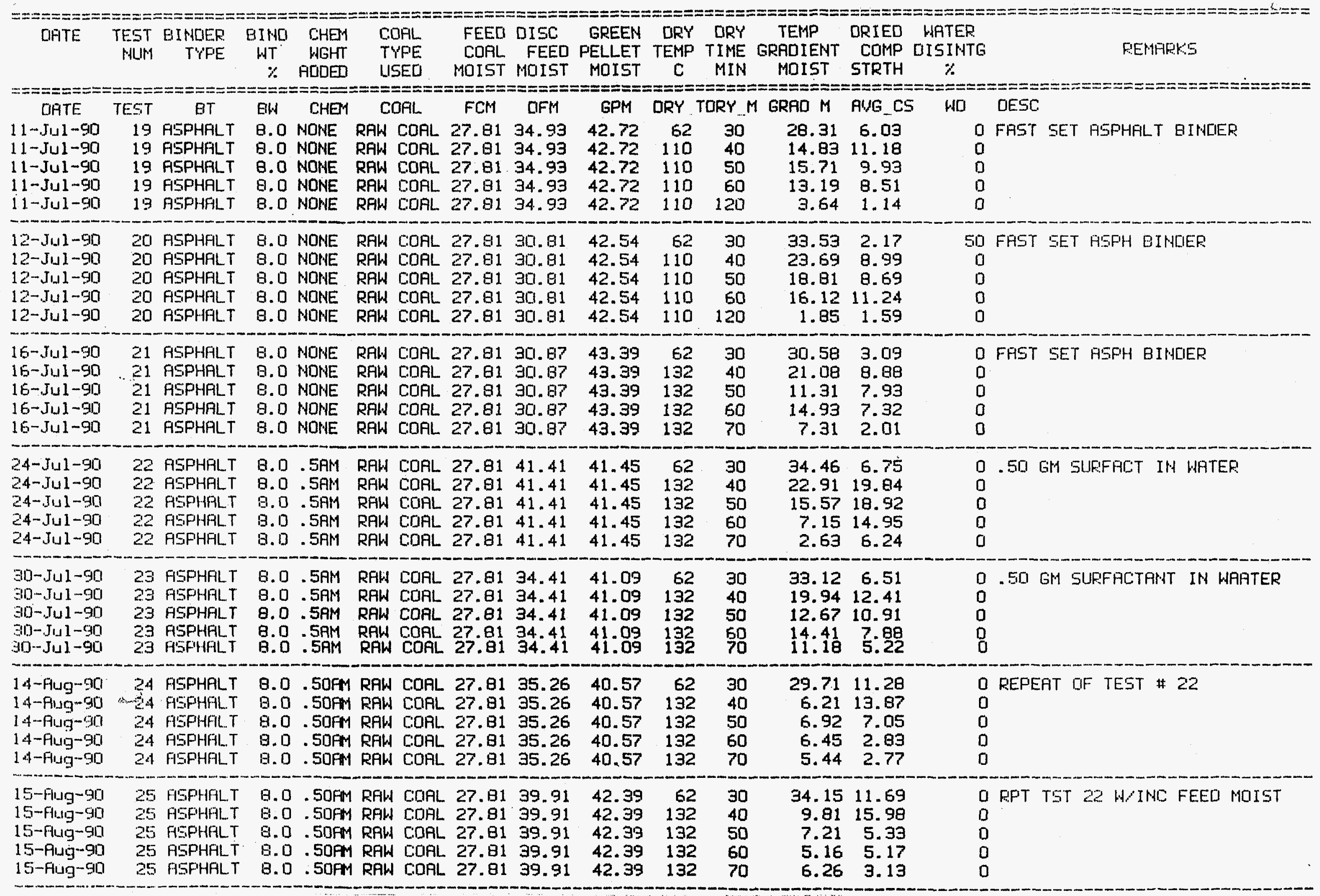


ARAK COFL PRODUCTS TESTING

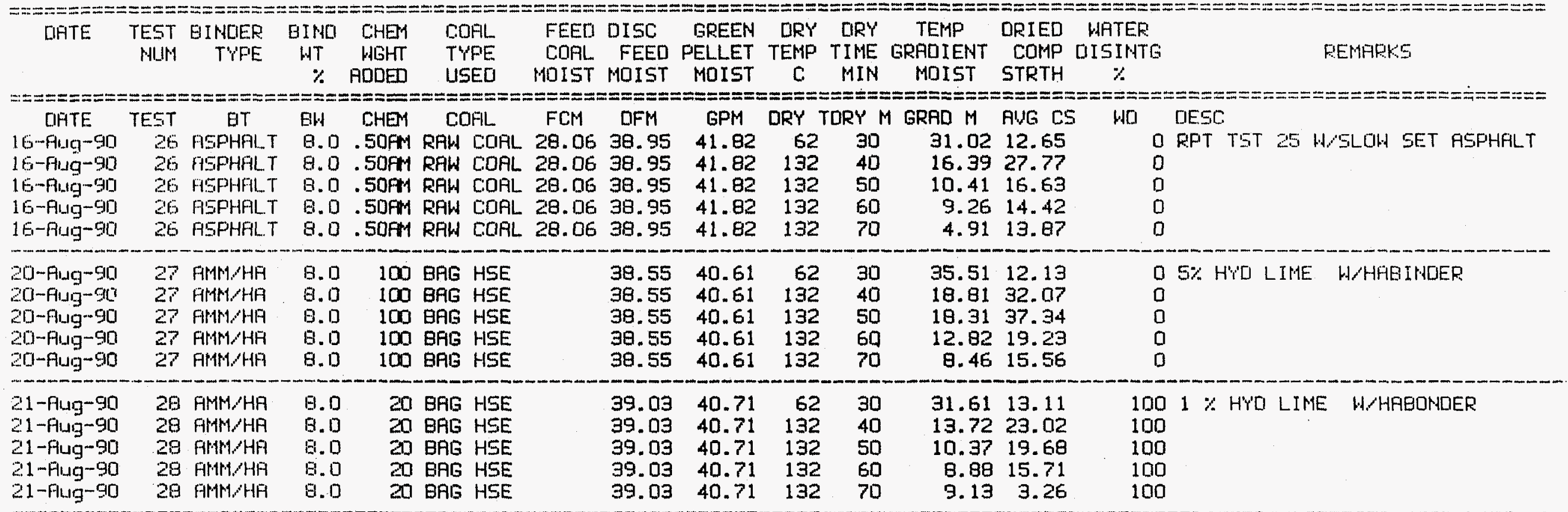

